\title{
Targeting the Water Network in Cyclin G-Associated Kinase (GAK) with 4-Anilino-quin(az)oline Inhibitors
}

\author{
Christopher R. M. Asquith, ${ }^{*[a, b]}$ Graham J. Tizzard, ${ }^{[c]}$ James M. Bennett, ${ }^{[\mathrm{d}]}$ Carrow I. Wells, ${ }^{[b]}$ \\ Jonathan M. Elkins, ${ }^{[d, e]}$ Timothy M. Willson, ${ }^{[b]}$ Antti Poso, ${ }^{[f, g]}$ and Tuomo Laitinen ${ }^{[f]}$
}

Water networks within kinase inhibitor design and more widely
within drug discovery are generally poorly understood. The
successful targeting of these networks prospectively has great
promise for all facets of inhibitor design, including potency and
selectivity for the target. Herein, we describe the design and

Inhibitor specificity and potency both present significant challenges in the development of kinase inhibitors and exploitation of kinase targets as potential therapies. The target profiles of commercial broad-spectrum kinase inhibitors are often challenging to rationalize in terms of direct molecular activity profiles. The large number of protein kinases present in the kinome $(>500)$ makes this task even more difficult. ${ }^{[1,2]}$ Protein kinases that are functionally distinct yet retain key structural features can show overlapping ligand preferences, both with near and distant neighbours on the kinome tree..$^{[3]}$

A number of strategies have been explored to address the specificity problem in kinases. ${ }^{[4]}$ These approaches include exploitation of size of the kinase gatekeeper residue, the

[a] Dr. C. R. M. Asquith

Department of Pharmacology, School of Medicine

University of North Carolina at Chapel HillmuDear author, please add city $\mathbf{\square}$ NC 27599 (USA)

E-mail: chris.asquith@unc.edu

[b] Dr. C. R. M. Asquith, C.I. Wells, Prof. T. M. Willson

Structural Genomics Consortium, UNC Eshelman School of Pharmacy

University of North Carolina at Chapel Hill

Chapel Hill, NC 27599 (USA)

[c] Dr. G. J. Tizzard

UK National Crystallography Service, School of Chemistry

University of Southampton

Southampton, SO17 1BJ (UK)

[d] J. M. Bennett, Dr. J. M. Elkins

Structural Genomics Consortium and Target Discovery Institute

Nuffield Department of Clinical Medicine, University of Oxford Old Road Campus Research Building, Oxford, OX3 7DQ (UK).

[e] Dr. J. M. Elkins

Structural Genomics Consortium

Universidade Estadual de Campinas - UNICAMP

Campinas, São Paulo, 13083-886 (Brazil)

[f] Prof. A. Poso, Dr. T. Laitinen

School of Pharmacy, Faculty of Health Sciences

University of Eastern Finland

70211 Kuopio (Finland)

[g] Prof. A. Poso

University Hospital Tübingen

Department of Internal Medicine VIII, University of Tübingen

72076 Tübingen (Germany)

Supporting information for this article is available on the WWW under https://doi.org/10.1002/cmdc.202000150

This article belongs to the Special Collection "Nordic Medicinal Chemistry 2019-2020" testing of a targeted library of 4-anilinoquinolines for use as inhibitors of cyclin G-associated kinase (GAK). GAK cellular target engagement assays, ATP binding-site modelling and extensive water mapping provide a clear route to access potent inhibitors for GAK and beyond.

disposition of the DFG-loop, chemotype selectivity, non-covalent interactions, salt-bridge, solvation, etc. Another method employed to obtain selective kinase inhibitors has been to target an allosteric site rather than the conserved ATP-binding site that is traditionally targeted and one that is unique to the kinase in question. Additionally, synthesizing inhibitors capable of covalent binding to a proximal cysteine has been successful to achieve selectivity over close family members. While each approach offers a possibility to achieve selectivity there is still a significant overall challenge to reach a successful endpoint. Identification and design of allosteric binders is challenging and most are found serendipitously. ${ }^{[5]}$ While inhibitors that modify the kinase covalently, first there has to be a residue capable of modification and then a way to assess the biological impact of that permanent modification. ${ }^{[6]}$

There has been a growing appreciation that solvent specific effects can make significant contributions to ligand binding. The impact of these effects are however, usually retrospectively applied as a post-rationalization of the observed results. ${ }^{[7-9]}$ Development of software to model these effects has progressed with enveloping distribution sampling (EDS), free energy perturbation (FEP) theory and displaced-solvent functional (DSF) all recently being developed. ${ }^{[10,1]}$ However, the use of WaterMap by Schrödinger, Inc. has significantly advanced the ability to study direct solvation effects such as solvent replacement. ${ }^{[12]}$

WaterMap couples molecular dynamics simulations with statistical thermodynamic analysis of water molecules within a protein structure. The method can provide insight not possible with traditional docking approaches. WaterMap was first used to rationalize the structure activity relationships of triazolylpurines binding to the A2 A receptor. ${ }^{[13]}$ Specifically, $n$-butyl and $n$ pentyl substituents resulted in unanticipated potency gains, but these structure activity relationships could not be readily explained by ligand-receptor interactions, steric effects, or differences in ligand desolvation.

WaterMap has also been used in a number of kinase inhibitor programs including Src family kinases, Abl/c-Kit, Syk/ ZAP-70, and CDK2/4 in order to rationalize kinase selectivity. ${ }^{[13]}$ Water modifications have also been shown to have a key effect 
in pivotal EGFR mutations showing resistance to afatinib and erlotinib. ${ }^{[14]}$ Molecular modelling studies on a PDGF-R $\beta$ homology model using prediction of water thermodynamics suggested an optimization strategy for the 3,5-diaryl-pyrazin-2ones as DFG-in binders by using a phenolic hydroxy group to replace a structural water molecule in the ATP binding site. ${ }^{[15]}$

This water network principle has also been applied to bosutinib, as the 3-cyanoquinoline allows the compound to engage with a pair of conserved structured water molecules in the active site of Src. ${ }^{[16]}$ This post-rationalization approach hints at a more powerful use of this idea in the design of new inhibitors to exploit the water network hypothesis in its entirety to address both potency and selectivity. ${ }^{[13]}$

In our work developing a selective chemical probe for cyclin $\mathrm{G}$ associated kinase (GAK), a member of the NAK subfamily. ${ }^{[17-21]}$ We observed two matched pairs of experimental results that did not fit with the expected structure activity relationship observed for GAK and the wider 4-anilinoquinoline scaffold (Figure 1). ${ }^{[17]}$

GAK is involved in a plethora of biological processes including cell cycle progression, ${ }^{[22]}$ Parkinson's disease, ${ }^{[23]}$ osteosarcoma ${ }^{[24]}$ and prostate cancer. ${ }^{[18,25]}$ Although GAK is a historically under-studied kinase, ${ }^{[26]}$ recent probe development efforts identified potent and selective inhibitors of GAK from multiple chemotypes, including isothiazolo[5,4- $b]$ pyridines, ${ }^{[27-28]}$ 4-anilinoquinolines and 4-anilinoquinazolines. ${ }^{[17-20]}$ These chem-

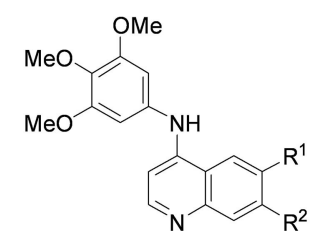

1: $\mathrm{R}^{1}=\mathrm{CF}_{3}, \mathrm{R}^{2}=\mathrm{H}-K_{\mathrm{i}}=3.9 \mathrm{nM}$

3: $\mathrm{R}^{1}=\mathrm{R}^{2}=\mathrm{OMe}-K_{\mathrm{i}}=0.54 \mathrm{nM}$

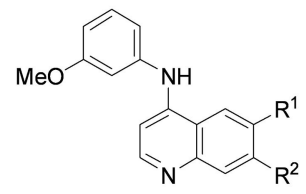

2: $\mathrm{R}^{1}=\mathrm{CF}_{3}, \mathrm{R}^{2}=\mathrm{H}-K_{\mathrm{i}}=5.7 \mathrm{nM}$

4: $\mathrm{R}^{1}=\mathrm{R}^{2}=\mathrm{OMe}-K_{\mathrm{i}}=2.5 \mathrm{nM}$
Figure 1. 4-Anilinoquinoline GAK inhibitor matched pairs with GAK activity shown.<smiles>COc1cc(-c2cnc3c(N4CCOCC4)snc3c2)cc(OC)c1OC</smiles>

JMC $2015-12 \mathrm{~g}$ $K_{\mathrm{d}}=8.9 \mathrm{nM}$

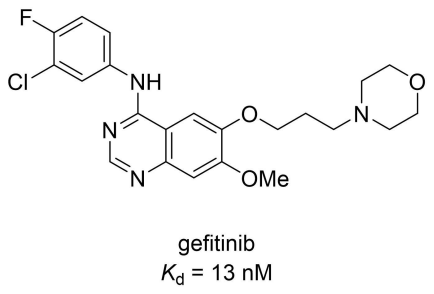

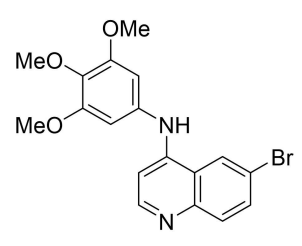

SGC-GAK-1 $K_{\mathrm{d}}=1.9 \mathrm{nM}$

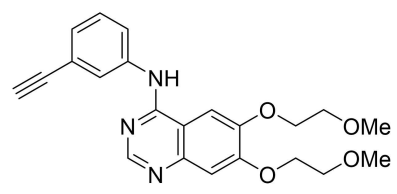

erlotinib $K_{\mathrm{d}}=3.1 \mathrm{nM}$
Figure 2. Previously reported GAK inhibitors. ical probes may be used in the future to study of the biology of GAK. ${ }^{[17,29]}$ In contrast to probes, several FDA-approved drugs (Figure 2), including EGFR inhibitors gefitinib and erlotinib, have been reported to show off-target GAK activity in the low nanomolar range (Figure 2). ${ }^{[30]}$

\section{Results}

The differently substituted matched pairs of trimethoxy- and meta-methoxy-substituted quinolines 1-4 showed potent binding to GAK with good NAK-family selectivity despite significant differences in both steric and electronic footprints. ${ }^{[17]}$ We looked for an alternative explanation for our observed equipotency and found through the application of WaterMap that there was a high-energy hydration site in the $p$-loop of the active site which is enabling both enhanced potency and NAK-family selectivity.

To further investigate this, we first looked at each NAK family member and observed that all have distinct water networks (Figure 3A-D). AAK1 and BIKE have a high degree of sequence identity in the kinase domain. ${ }^{[21]}$ There are some key residue differences located at the hinge region of each NAK family member: Leu125 (GAK)/Phe100 (STK16)/Tyr132 (BIKE)/ Phe128 (AAK1), and Phe101 in STK16 in place of Cys126 (GAK)/ Cys133 (BIKE)/Cys126 (AAK1). There are also alterations in the back pocket, where polar Thr123 and other bulkier residues like Leu98 (STK16) are located in case of GAK and Met130 and Met126 in case of BIKE and AAK1. Respectively, these alterations have significant impacts on the binding modes of inhibitors (Figure 3A, B). ${ }^{[20]}$ While the other three family members have lipophilic residues that have no ability to behave as a hydrogen bond donor/acceptors, GAK has Thr123 that can perform both functions. Moreover, the rotamer of Thr123 is likely fixed in place by an internal hydrogen bond to the backbone carbonyl group of Glu124 (Figure 3C, D).

This also gives rise to differences in the predicted water networks of the four NAK kinases (Figure 4A-D). However, only GAK has a high-energy hydration site likely due to small pit created by the interaction between Thr123 and Glu124 (Figure 4A). A hydration site is considered to be high in energy when the relative free energy value from WaterMap analysis has a high positive value, that is, $5.9 \mathrm{kcal} / \mathrm{mol}$ in case of GAK. There can be two cases when the hydration site has unfavourably high energy. First, water solvating hydrophobic enclose such as in the case of GAK third strand of beta sheet ( $\beta 3$ ) between Lys69 and Thr123. This type of cavity is energetically unfavourable (due to enthalpy) because water molecules cannot form a full complement of hydrogen bonds with surroundings. Second, is where the binding is entropically unfavourable, partly due to the closed nature of the hydration site. This is where water can form hydrogen bonds but suffers from reduced number of hydrogen bond configurations with protein groups and partner waters. Replacement of a water from such hydrations sites often may lead to improvement in affinity. Despite 17 sequence differences between GAK and AAK1/BIKE in the ATP binding domain; ${ }^{[21]}$ the only significant difference in 
A

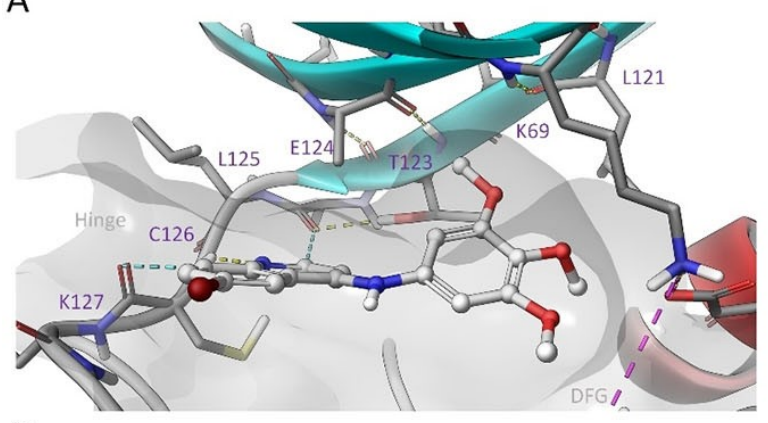

C

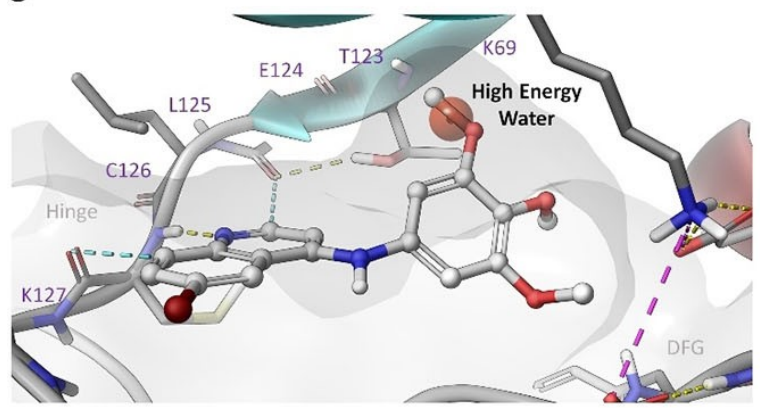

B
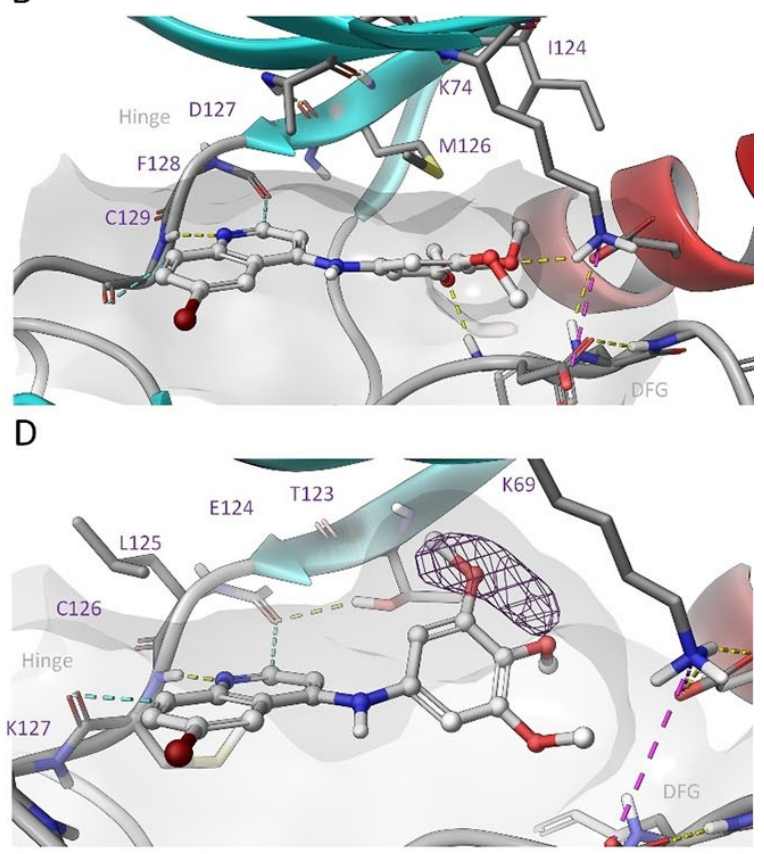

Figure 3. A) Additional space close to the $\beta$-sheet at the back pocket is occupied in the favourable docking pose of compound SGC-GAK-1. B) In comparison, in the case of AAK1, the corresponding back pocket area is filled by the methionine side chain (same location as Thr123 in GAK). C) An orange sphere shows the location of high-energy $(5.9 \mathrm{kcal} / \mathrm{mol})$ hydration site in GAK. D)The high-energy hydration site is actually dewetted (very low water occupancy) in WaterMap simulation.
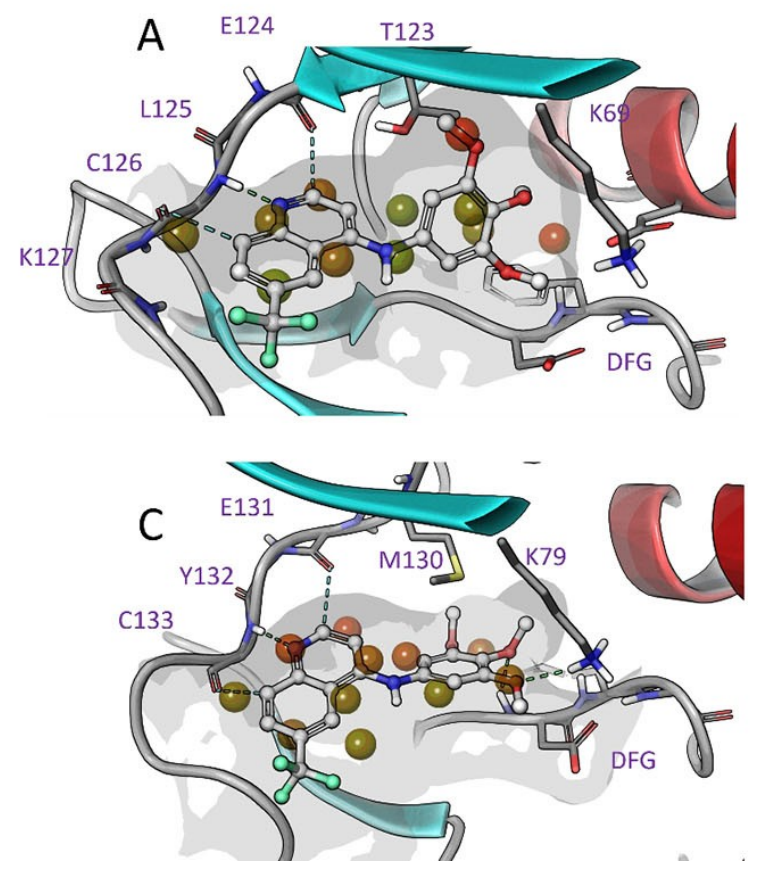
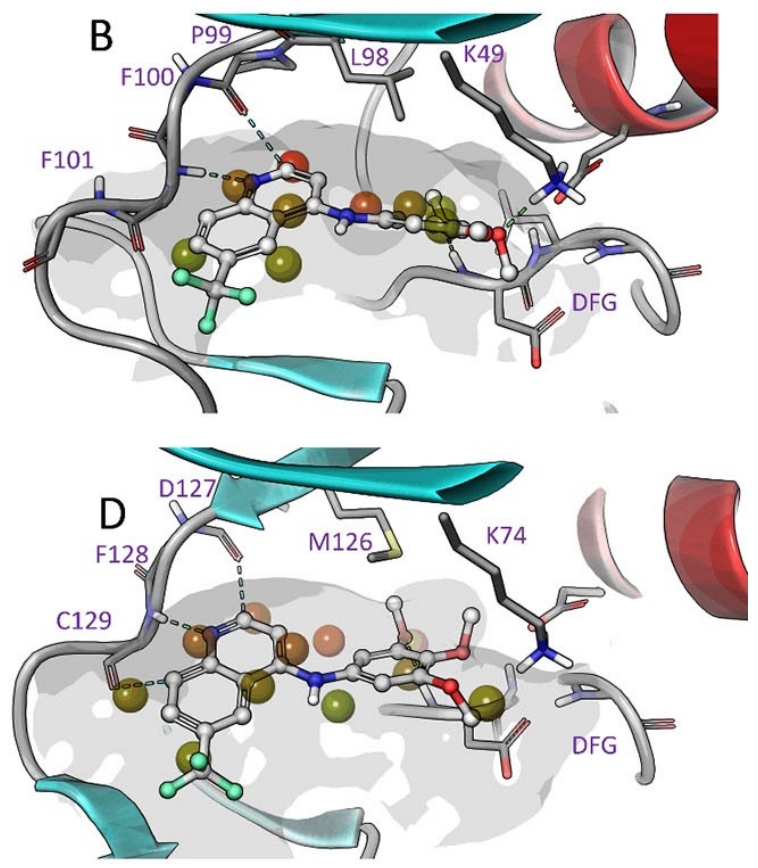

Figure 4. Molecular modelling of 1 in the water network of NAK family members by using WaterMap (high-energy waters are highlighted in red, lower-energy waters are in green): A) GAK (PDB ID: 5Y80); B) STK16 (PDB ID: 2BUJ); C) BIKE (PDB ID: 4 W9X); D) AAK1 (PDB ID: 5TE0).

the water network is the presence of the high-energy water in the $p$-loop region (Figure $3 A-D$ ). The most structurally diverse NAK family member STK16 has 64 differences in the kinase sequence compared to the other NAK kinases in the ATP binding domain. STK16 has a significantly different water network compared to the other NAK family members but does 

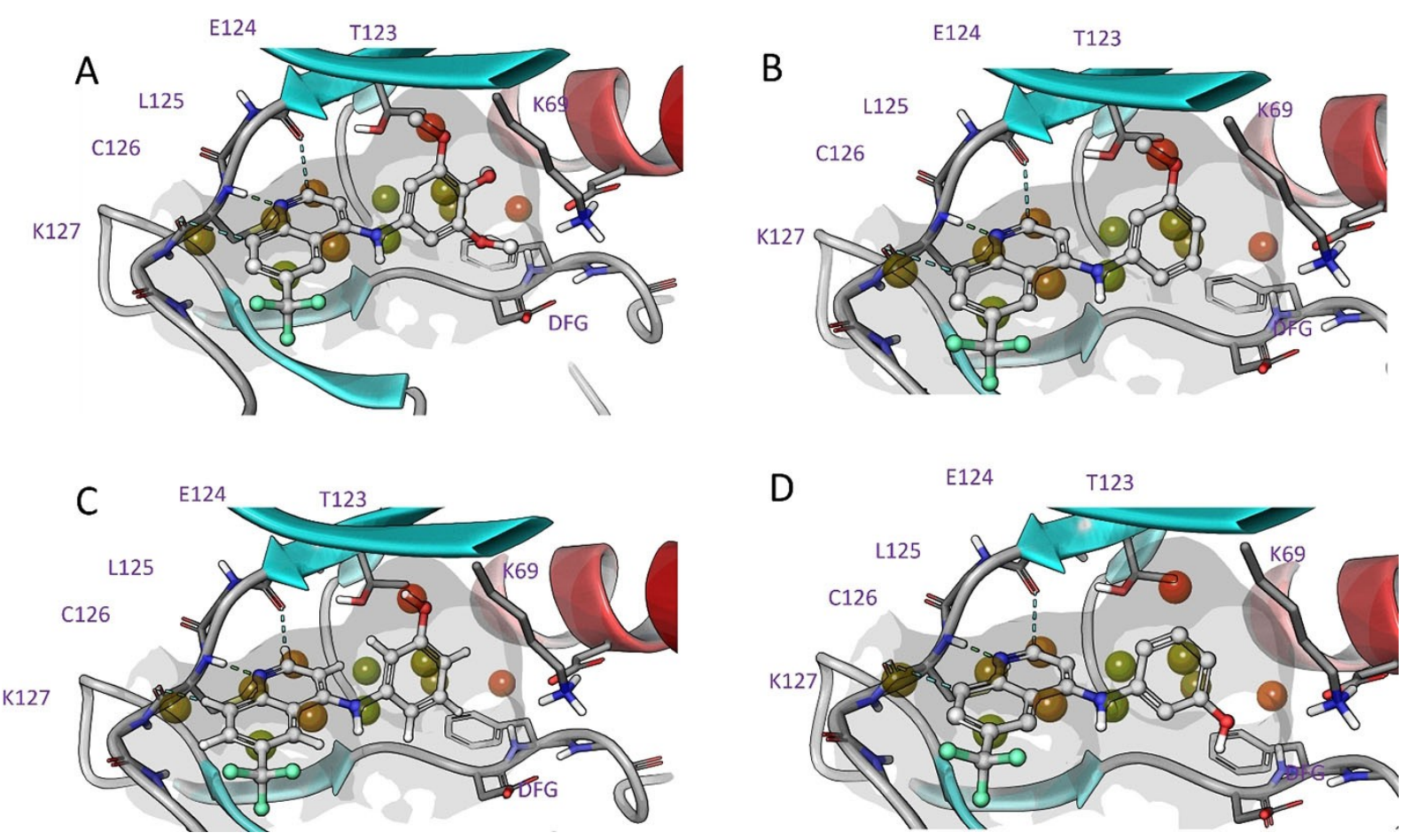

Figure 5. WaterMap modelling of GAK where high-energy waters are highlighted in red, lower energy waters are in green (PDB ID: 5 Y80), with A) 1 ; B) 4; C) 5 and D) 5.

possess a high-energy water that is in a $7 \AA$ out of plane orientation related to the GAK protein structure (Figure 4A, D).

Through a series of prospective simulations using WaterMap we identified that this additional high-energy hydration site next to the spine of the ATP binding pocket makes the shape of the GAK binding back pocket rather different to other NAK kinases studied (Figure 4). ${ }^{[31]}$ A hydrophobic furrow is formed next to Thr123, where the side chain is hydrogen bonded to the backbone carbonyl group of Glu124, and is rather small in size overall. While in case of other NAK kinases there is either a bulky methionine (AAK1 and BIKE) or lle110 in the case of STK16 (Figure 3A, B). As a consequence, in the case of GAK, this hydrophobic site can be readily occupied by a ligand substituent without side chain rearrangements.

The water network simulation of the 6-(trifluoromethyl)- $N$ (3,4,5-trimethoxyphenyl)quinolin-4-amine (1) versus meta-methoxy derivative 2 demonstrated plausibility of the high-energy water displacement to explain the almost equipotent high GAK activity (Figure 5A, B). The slight increase in potency could be attributed to the rearrangement of the catalytic lysine to sit between the two additional methoxy groups in 1. Reforming of the water contacts by removal of the methyl group from the methoxy group (5) showed an encouraging ability to lock the phenolic $-\mathrm{OH}$ in place in the preferred docking pose (Figure 5 C). Compound 5 could also be forced to adopt a higher energy conformation where the $-\mathrm{OH}$ interacts with the catalytic lysine (Figure 5D). The new $\mathrm{H}$-bond lysine interaction is not compensating the two $\mathrm{H}$-bonds replacing the high-energy water. Although metabolically liability of a phenolic $-\mathrm{OH}$ is well known, it is a strong proof of concept substitution. ${ }^{[32]}$

To further probe the structural requirements for GAK activity and the water network, we synthesized a series of analogues (Scheme 1). 4-Anilinoquinolines were prepared by heating the corresponding 4-chloroquinoline derivative and substituted aniline in ethanol with Hünigs base and refluxed overnight. ${ }^{[17-20,33-34]}$ The synthesis afforded products 1-34 in good yield (58-86\%). Interestingly, the more activated reaction to 6-bromo-4-chloroquinoline-3-carbonitrile was completed in two hours to afford 31 in good yield (69\%). The hydrogenations of the nitro derivatives $\mathbf{7}$ and $\mathbf{2 1}$ to form $\mathbf{8}$ and $\mathbf{2 2}$ were routine with good to excellent yields ( 69 and $94 \%$ respectively).

The compounds were initially screened for activity on the kinase domains of all four members of the NAK family members

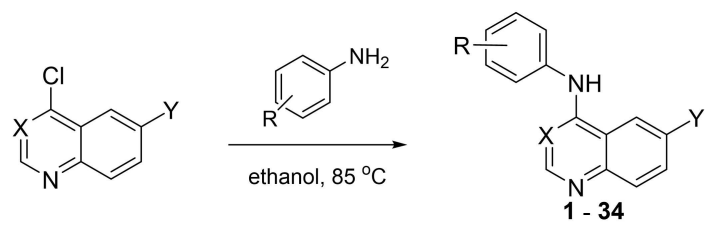

$\mathrm{X}=\mathrm{CH}, \mathrm{N}, \mathrm{C}-\mathrm{CN}$ $\mathrm{Y}=\mathrm{CF}_{3}, \mathrm{Br}, \mathrm{H}, \mathrm{OMe}, \mathrm{SO}_{2} \mathrm{Me}$
$\mathrm{X}=\mathrm{CH}, \mathrm{N}, \mathrm{C}-\mathrm{CN}$ $\mathrm{Y}=\mathrm{CF}_{3}, \mathrm{Br}, \mathrm{H}, \mathrm{OMe}, \mathrm{SO}_{2} \mathrm{Me}$

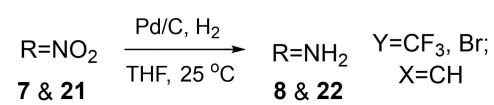

Scheme 1. General synthetic route to analogues 1-34. 
(GAK, AAK1, BMP2 K, and STK16) using a time-resolved fluorescence energy transfer (TR-FRET) binding displacement assay in a 16-point dose response format to determine the inhibition constant $\left(K_{\mathrm{i}}\right)$. The compounds were then screened in a cellular target engagement assay nanoluciferase (nanoLuc) bioluminescence resonance energy transfer (BRET; NanoBRET) assay for GAK. ${ }^{[17-18,35-36]}$ The sensitive nature of the assay allows a complimentary comparison to the TR-FRET to observe subtle trends in the GAK inhibition profile.

The background provided by $\mathbf{1 - 4}$ and Figure $3 A-D$ led us to probe around the 6-trifluorometyl substituted quinolines with some small modifications looking for potential hydrogen bond interactions to further boost the initial potency in the structure activity relationships observed (Figure 1). ${ }^{[1]}$ The trimethoxy compound 1 demonstrated high affinity for GAK and good selectivity against the rest of the NAK family members. A switch from the trimethoxy- (1) to the meta-methoxy-substitution (2) showed almost equipotency consistent with previous reports. ${ }^{[17]}$

The GAK NanoBRET showed an almost 3-fold drop in cellular target engagement from $\mathbf{1}$ to 2 . This effect is still impressive as the meta-methoxy derivative $\mathbf{2}$ is able to substitute the trimethoxy functionality despite not occupying the same space orientation. ${ }^{[16]}$ A switch from meta-methoxy (2) to meta-hydroxy (5) showed a slight increase in GAK binding but not as significantly as the modelling predicted (Table 1 ).

We then switched to a meta-nitro group (6) or meta-amino group (7) to investigate the possibility of forming multiple hydrogen bonds. ${ }^{[3]}$ However, both 6 and 7 proved to be relatively ineffective with a 45 - and 25 -fold decrease in GAK binding respectively and a low micromolar cellular target engagement. The addition of two methyl groups to the amine (8) demonstrated a 5 -fold decrease in GAK potency $\left(\mathrm{K}_{\mathrm{i}}=\right.$ $650 \mathrm{nM}$ ). The removal of the trifluoromethyl group of 7 and 8 to form 9 and 10 respectively showed the same trend in GAK potency but a 4 -fold increase in selectivity (8 vs. 10). We returned to the hydroxy moiety and inserted a methyl linker between the aniline with the aim to effectively generate a hydrogen bond interaction with Thr123. The methanol analogues 11 and 12 proved to be 10-fold weaker on GAK, likely due to spatial constraints in the top pocket of the ATP binding site.

The NAK family selectivity pattern observed with 1-5 hinted at a potential water displacement. With this in mind we explored a series of meta-methoxy and meta-hydroxy matched pairs (Table 1). Compound 2 has a favourable NAK family profile towards GAK and has previously been shown to have a narrow spectrum profile across the kinome. ${ }^{[19]}$ The 6-bromoquinoline (13-14) is the optimal substituent for GAK inhibition on this scaffold (Table 2). ${ }^{[17-19,34]}$ This substitution offers optimal GAK binding in the solvent exposed mouth of the ATP binding site and potent GAK inhibition at lower concentrations. The switch from the trimethoxy to the meta-methoxy substitution (13) was equipotent to the binding of $\mathbf{2}$ on GAK; but with a corresponding drop off in NAK selectivity and NanoBRET activity. The switch from 13 to the hydroxy substituted compound 14 shows an almost threefold increase in $\mathrm{K}_{\mathrm{i}}$ which was more pronounced in the cellular assay with an almost tenfold increase from an $\mathrm{IC}_{50}$ of 218 to $26 \mathrm{nM}$.

The removal of the 6-bromo to the unsubstituted quinoline analogue 15 resulted in a tenfold drop in potency of metamethoxy (15); with the hydroxy (16) only giving a limited increase in GAK affinity. The NanoBRET results for 15 and 16 were weaker but consistent with the trend observed. The 6methoxy- $N$-(3-methoxyphenyl)quinolin-4-amine (17) showed good activity that tracked with the previously reported trimethoxy derivative. ${ }^{[17]}$ However, the switch from trimethoxy to meta-

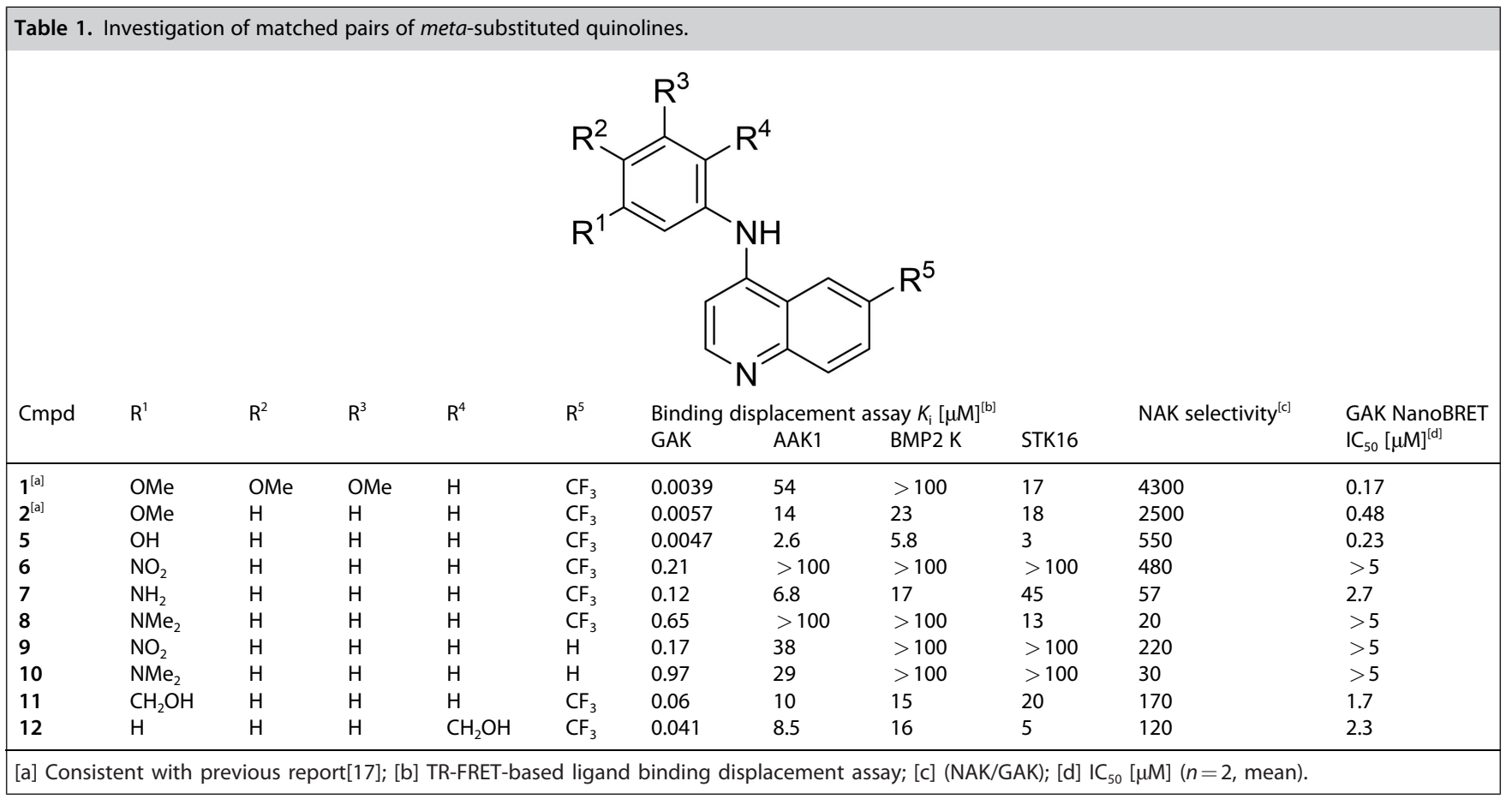




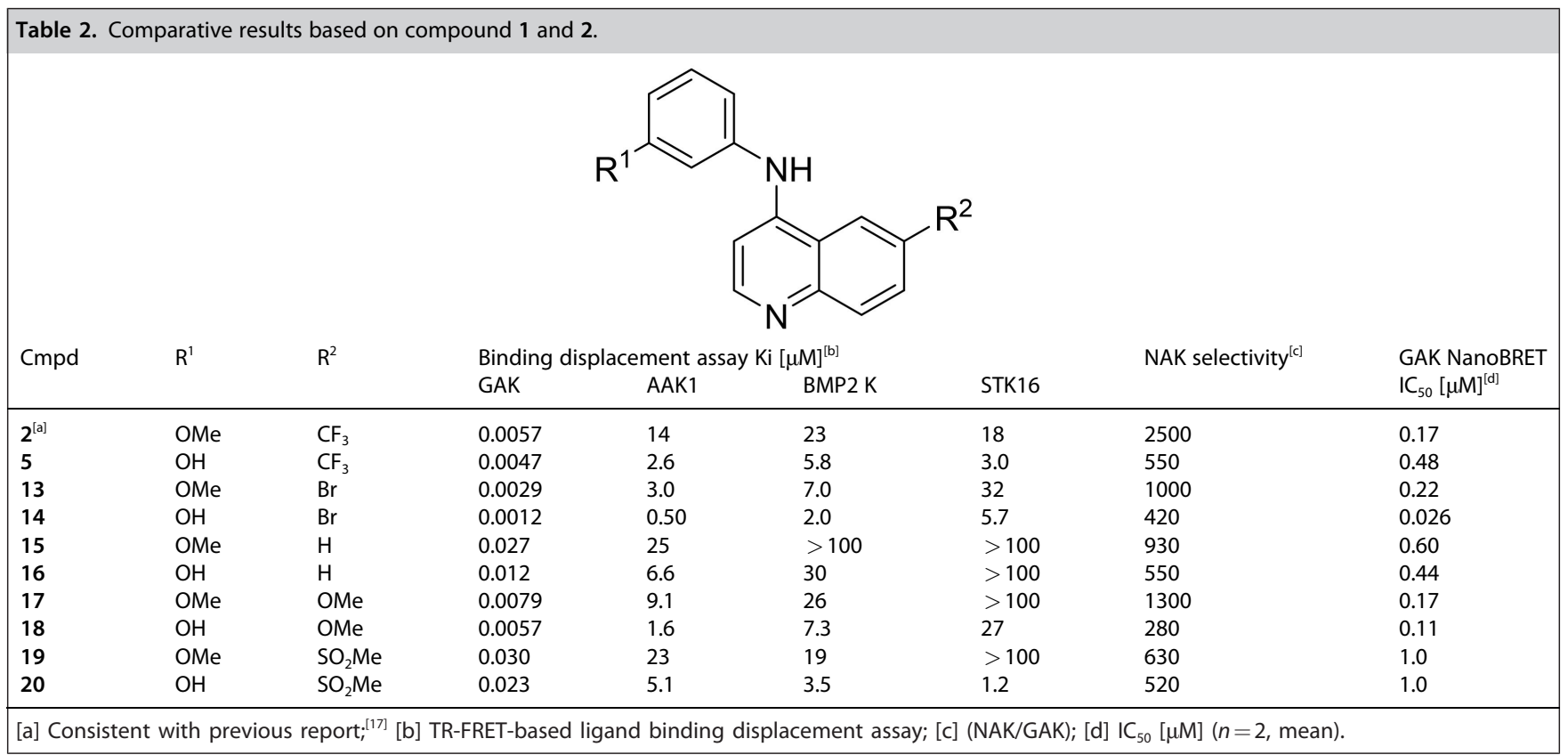

methoxy substitution resulted in a NAK selectivity drop of sixfold. ${ }^{[16]}$ The switch to the hydroxy moiety (18) gave only a slight increase in GAK activity and the same NAK selectivity as the previously reported trimethoxy compound 3 . This trend was repeated in the GAK NanoBRET. The 6-methyl sulfone metamethoxy (19) was a weaker GAK binder consistent with previous structure activity relationships observed on this scaffold. ${ }^{[17]}$ The trend observed between 13 and 14 provided the strongest evidence yet that the potential water was being displaced (Table 2). A further switch to the nitro substitution with the 6-bromoquinoline $\mathbf{2 1}$, was ten times more active than the corresponding 6-trifluoromethyl compound 6 (Table 3). This further supports the rational that the 6-trifluoro quinoline does not allow the optimal orientation when compared to the 6bromoquinoline.

However, surprisingly the meta-amino group of the 6-bromo compound 22 was three times less potent on GAK than 7. The dimethyl amino aniline derivative $\mathbf{2 2}$ was broadly in line with expectations with similar potency to the 6-trifluoromethylquinolines $\mathbf{7}$ and $\mathbf{8}$. The switch from an oxygen atom to a nitrogen atom reduces GAK potency which would suggest that the electronegativity of the oxygen atom is required for the

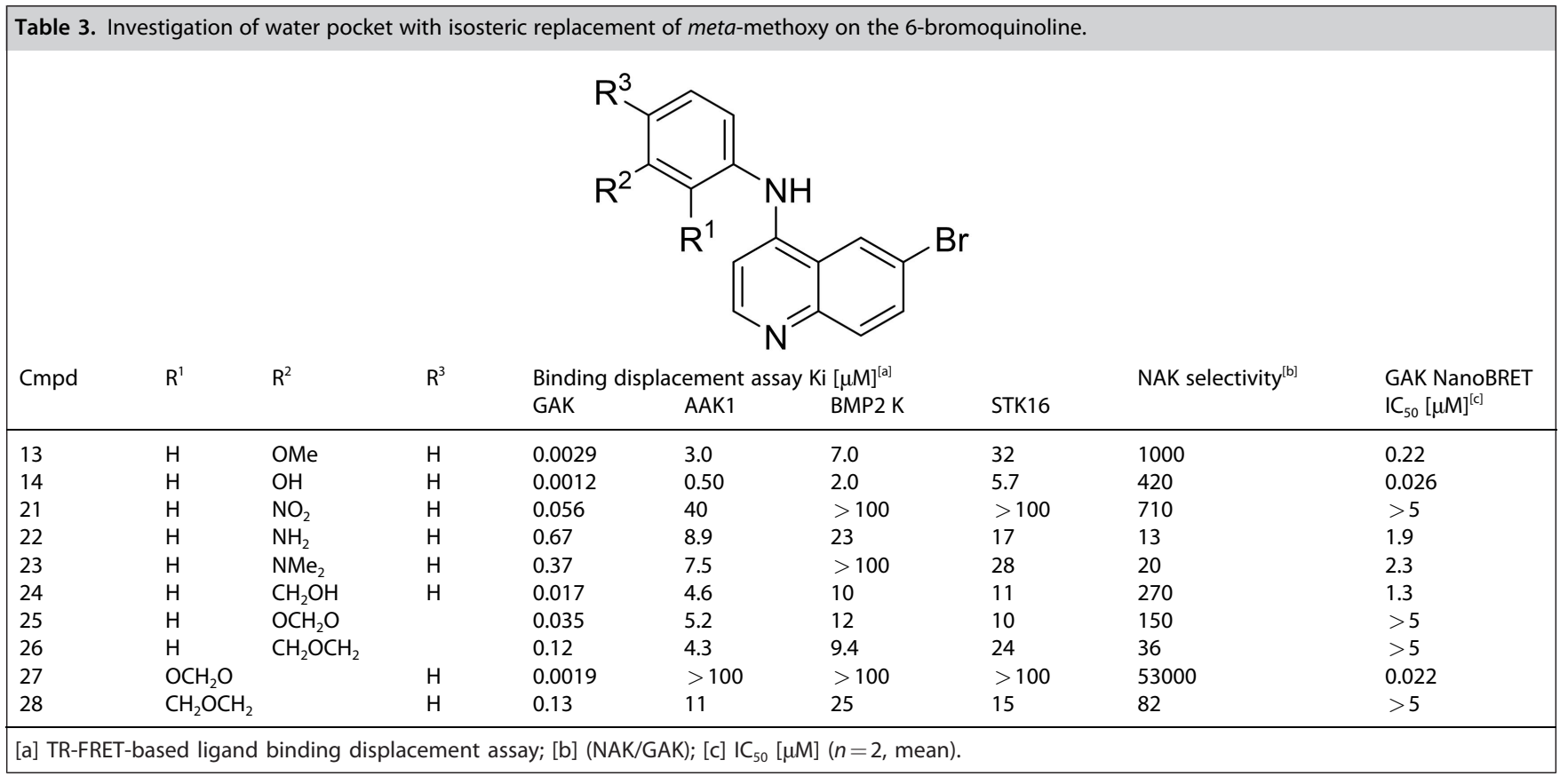


optimal replacement of the water. ${ }^{[38]}$ The meta-methanol derivative $\mathbf{2 4}$ showed only a limited improvement towards GAK binding compared to the 6-trifluoromethyl (11).

We then explored how torsional strain on the methoxy orientation and constrained ring systems would affect the GAK activity profile. The fused ring systems (25-28) demonstrate how sensitive the water network is and how an island of activity can be achieved. Compounds $\mathbf{2 5}$ and $\mathbf{2 7}$ demonstrate the same effect as 1 and 2 . The 3,4 connectivity (25) vs 2,3 connectivity (27) showed a preference for the orthogonal plane angle and an ability to accommodate this in the ATP pocket. However, with 25 , the rotational energy penalty combined with constraints at the 4-position accounts for a 14-fold drop in potency on GAK (25 vs. 27).

The drop is more severe with the mono-substituted central oxygen which produces two equipotent compounds (26 and 28) regardless of positioning (Figure $S 1$ ). The result was the identification of a potent cell active GAK inhibitor (27).

We then looked at the conformation of the compounds and the influence this has on the potential water displacement (Table 4). Switching from the quinoline meta-methoxy aniline (13) to quinazoline (29) results in a 4-fold penalty, likely related to the flattening of the molecules conformation. The corresponding meta-hydroxy analogue $\mathbf{3 0}$ was equipotent with 29 in GAK binding, likely due to the inability to effectively form the hydrogen bond to replace the water molecule due to the planer character of the compound. Switching back to the 6-bromoquinoline, meta-tetrazole $\mathbf{3 1}$ with the potential to form multiple hydrogen bonds, mimicked the nitro substitution (21) in potency and selectivity despite occupying a large space. The three compounds pentafluorosulfanyl (32), ${ }^{[39]}$ tert-butoxy (33) and the tert-butyl (34) were likely too large and lipophilic with each demonstrating GAK binding $\left(\mathrm{K}_{\mathrm{i}}\right)$ between 2 and 3 micromolar. This highlights the requirement for small, precisely oriented hydrogen bond donors with correct torsional strain to effectively displace the water and form a strong interaction.

In order to rationalize the results observed (Table 1-4) we modelled key compounds SGC-GAK-1, 13, 14, and 25-28 in the GAK ATP competitive active site with Glide module of Schrödinger Maestro suite (Figure S1). ${ }^{[40]}$ We observed through docking that unlike SGC-GAK-1, the meta-methoxy derivative (13) was not able to form an interaction with the catalytic lysine (Lys69). This runs counter to the observed GAK binding where SGC-GAK-1 and 13 have near equipotency despite this interaction deficit, suggesting other factors including the water network.

The docking of quinazoline $\mathbf{2 9}$ demonstrated a lack of the correct orientation to form optimal binding to GAK (Figure S1). The docked meta-hydroxy (14) proposed direct interaction with the alcohol altering the through molecule orientation to form a rarely reported sigma hole interaction (halogen bond) directly with the 6-position bromine mediated through a water molecule bound next to the carbonyl from Leu46 (Figure S2). ${ }^{[4]}$ During our investigations this result was not observed with any other analogue. The 5-membered dioxane derivative $\mathbf{2 7}$ demonstrated the ability to form an optimal fit while still displacing the water (Figure S1). Surprisingly none of the other closely related derivatives $\mathbf{2 5}, \mathbf{2 6}$ and $\mathbf{2 8}$ were able to achieve this (Table 3).

The WaterMap simulations demonstrate the ability of the most potent GAK inhibitors in the NanoBRET SGC-GAK-1, 13, 30 and $\mathbf{2 7}$ to displace the high-energy water present in the hydrophobic pocket. The displacement of this high-energy water provides a significant boost of binding affinity. SGC-GAK1 was able to displace the water and interact with the catalytic lysine (Figure 6A). The meta-methoxy derivative 13 was able to interact with the catalytic lysine but preferentially chose to displace the water (15/15 simulations; Figure 6B). The WaterMap simulation also demonstrated that the quinazoline 30 had a

\begin{tabular}{|lllll}
\hline Table 4. Investigation of water pocket with isoteric replacement of meta-methoxy group and different hinge binders. \\
\hline
\end{tabular}



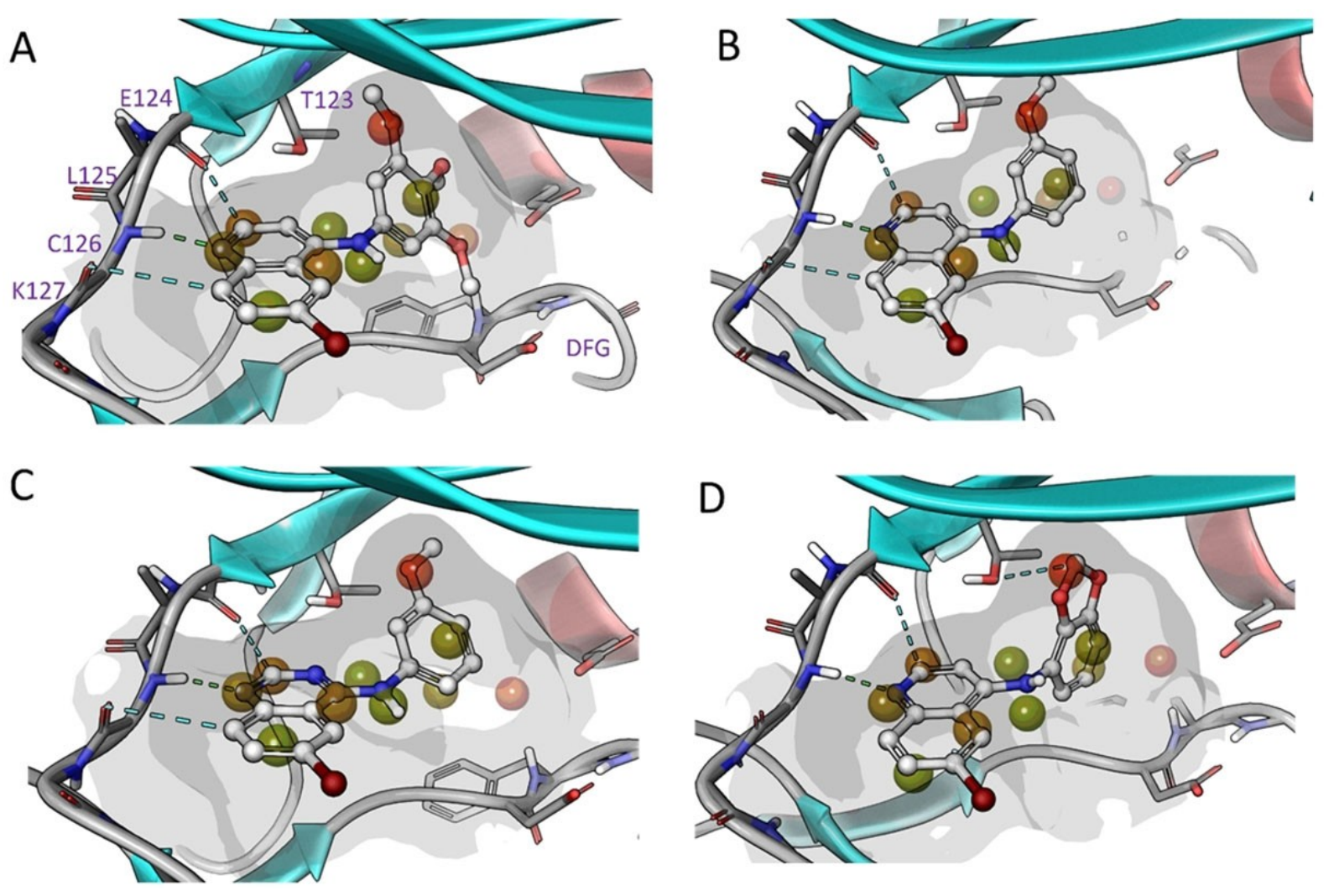

Figure 6. Main WaterMap hydration sites overlaid with selected ligands A) SGC-GAK-1, B) 13, C) 30 and D) 27 in the GAK ATP binding domain.

more flexible conformation and hence was able to only partially displace the water molecule (Figure 6C). The 5-member dioxane number was set up in the correct orientation to displace the water molecule (Figure 6D). Interestingly, while 25, 26 and 28 were good binders they were not well set up to displace the high-energy water or form key interactions in the ATP binding site of GAK (Figure S1).

In order to investigate the bound water hypothesis further and to further elucidate what constitutes a high and low energy water within the GAK kinase domain we searched for 'dry areas' within the ATP binding pocket. These are portions of the receptor active site that are so unfavourable for water molecules that a void is formed there. These are uncommon but have been theoretically and experimentally been observed. ${ }^{[42]}$

The WaterMap analysis of APO structure of GAK (Figure 7A) and ligand binding form (Figure 7B) of GAK demonstrated that water bound to the high-energy pocket had a low relative occupancy of 0.42 in case of APO and 0.53 in case of gefitinib bound, respectively. These low occupancies highlight that there is space, but the positioning of the water is sub-optimal even though a pocket of space available.

Hydration site analysis with bound gefitinib (Figure 7C) showed the pocket present but is only partly occupied by the aniline portion of gefitinib. When gefitinib is switched for SGCGAK-1 (Figure 7D) the hydration site analysis indicates that all the sites are occupied with ligand substituent arms on the trimethoxyaniline portion of the molecule. This provides further explanation for high affinity and enhanced specificity of SGCGAK-1 and the current series of ligands. An interesting feature of the GAK ATP binding site is that Thr123 is not able to occupy that space at roof of the back pocket which is the origin of this 'dry' area.

The observed torsional effects of the aniline to quin(az)oline ring system observed with 13 vs 29 were further explored by solving a series of small molecule crystal structures of 13, 14, 25, 27 and 29 (Figure 8). The chloride salts of 13, 14, 25 and 27 crystallized and as expected, hydrogen bonding between the amine (and alcohol; 13), amine donors and chloride counter-ion are the dominant intermolecular interactions within these structures, leading to simple hydrogen bonded 1D chains in each case. Additionally, $\mathbf{1 3}$ and $\mathbf{2 5}$ crystallize as hydrates with disordered water molecules in channels parallel to the $a$ - and caxes respectively resulting in more complex 3D hydrogen bonded networks. Only 29 crystallizes as a pure substance and also forms 1D hydrogen bonded chains via the aniline and quinazoline 1-position nitrogen. Structures 13 and 29 crystallize with two independent molecules in the asymmetric unit related by approximate inversion in both cases. The $\mathrm{C}-\mathrm{N}-\mathrm{C}-\mathrm{C}-\mathrm{C}$ torsion angles of 12, 13, 25, 27 and 29 occur in narrow range between $\pm 32.4(8)^{\circ}- \pm 61.62(18)^{\circ}$ with 12 and 27 displaying torsion angles $> \pm 50^{\circ}$ The functional groups of the aniline moiety are positioned above the rotation axis of the aniline ring 

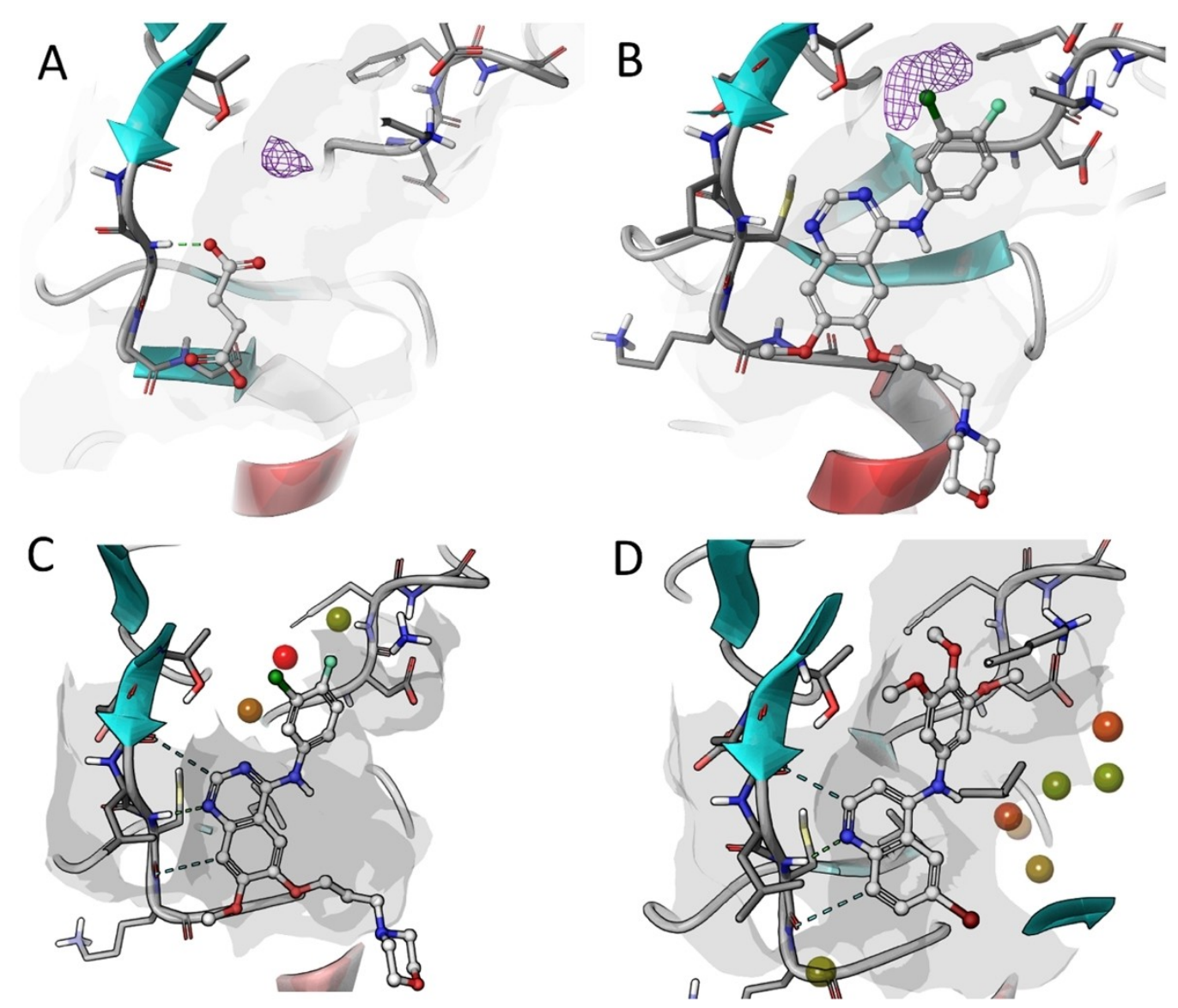

Figure 7. A) GAK APO structure WaterMap (PDB ID: 4C38); B) showing dewetted area extracted from WaterMap simulation overlaid with gefitinib (PDB ID: 5Y80); C) WaterMap simulation with gefinitib bound to GAK (PDB ID: 5Y80); D) WaterMap simulation with SGC-GAK-1 bound to GAK (PDB ID: 5 Y80).

A

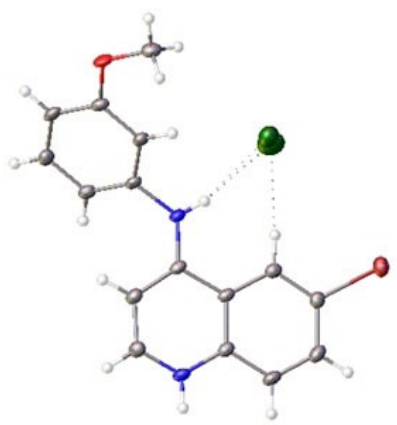

B

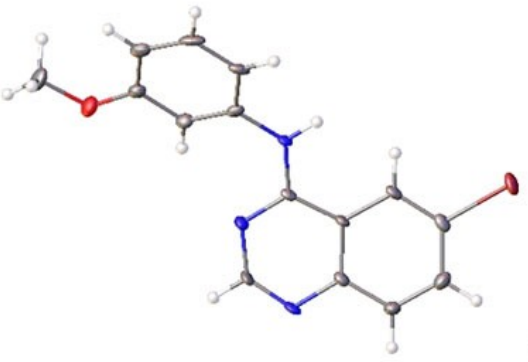

C

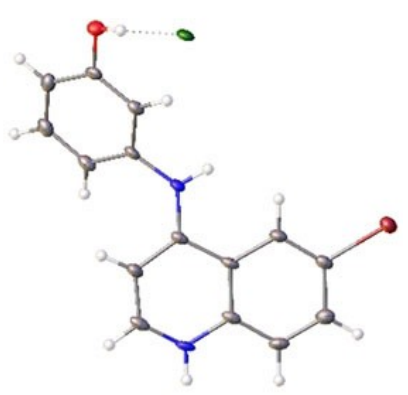

\section{D}

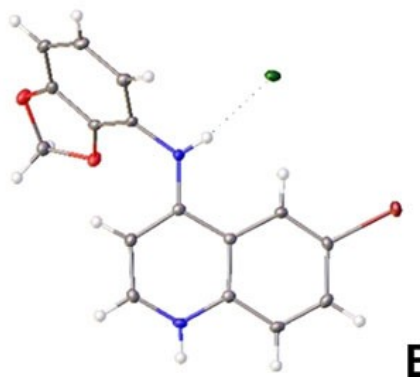

E

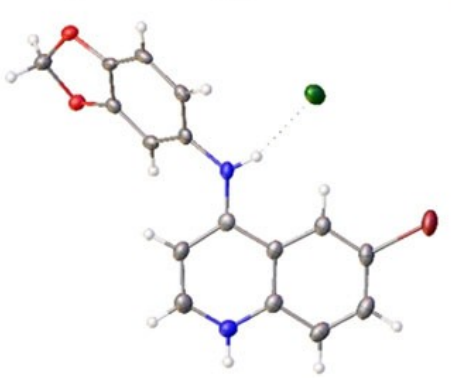

Figure 8. Crystal structures of A) 13, B) 29 , C) 14, D) 27 and E) 25 . ADP ellipsoids are displayed at $50 \%$ probability. Counter ions are shown but solvent molecules are not shown for clarity. 
of 12 and 13 whereas they are below the axis of rotation in 25 , 27 and 29.

\section{Discussion}

The tractability of protein kinases is well known, with more than 50 inhibitors targeting the ATP binding site of kinases approved for use in the clinic. ${ }^{[43]}$ However, most of these drugs leverage the conservation of the ATP binding pocket across kinases to increase their clinical efficacy. ${ }^{[31]}$ These multikinase inhibitors, although effective, would not be well suited outside oncology indications. Development of kinase inhibitors for new treatments outside of oncology will require inhibitors with significantly improved potency and selectivity profiles. ${ }^{[4]}$ Novel approaches to tackle this issue are urgently required in order to effectively develop highly selective and potent kinase inhibitors to target the conserved ATP binding site outside oncology indications.

Several tools to achieve this aim are available with binding assays enabling rapid, accurate and robust method to assess potency and potentially wider selectivity of ATP-competitive kinase inhibitors. ${ }^{[45-46]}$ These ligand binding displacement assays also provide an accepted direct measurement of kinase inhibition in drug optimization of ATP binding site inhibitors. ${ }^{[45]}$ This is a particularly acute point in the case of more neglected kinases such as GAK where there are currently no robust and validated enzyme activity assays. ${ }^{[4]}$

The water network is not a novel concept but has so far attracted limited attention. This is partially due to the fact that targeting and predicting the water network is difficult and, in some cases, not precise enough. WaterMap and other solvent prediction systems have attempted to bridge this gap while other efforts including the KILFS database have attempted to map the ATP binding sites across the kinome. ${ }^{[48]}$ Direct use of WaterMap has been demonstrated to enable, assess and design selectivity within PI3 K subtypes $(\alpha, \beta, \gamma$, and $\delta$ ) which have highly similar ATP binding sites. The critical role of water molecules in molecular recognition is under recognized and could provide a useful rationalization to drive down potency and improve selectivity. ${ }^{[49]}$

WaterMap analysis of the GAK ATP binding site suggested that a coordinated water network in the protein pocket spans the region proximal the aniline and the 6-position of the ring system. However, one poorly coordinated higher energy water molecule within this network is able to be targeted and displaced. The effect of this displacement leads up to a tenfold boost due to entropic and enthalpic contributions to the free energy of binding (Figures 4,-6). These models suggest that a water network within the GAK active site plays a critical role in defining the relative affinity of quinoline ligands. Extension of this model to other NAK family members demonstrates why the 4-anilinoquinoline is significantly more potent on GAK compared to the other NAK family members that lack that higher energy water molecule in the lipophilic pocket of the ATP binding site within GAK (Figures 3 and 4). The influence of different substituents on the preferred fragment pose was analysed by various computational approaches. The orthogonal off-targets between 1 and JMC 2015-12 g led us to postulate that the replacement of water molecules results in different flipped binding modes between the two scaffolds (Figure 9A, $B)$. This was supported by several computational studies in the literature, ${ }^{[49-50]}$ in addition to a series of oxindole derivatives demonstrating selective DYRK inhibition by a water induced flipped binding mode. ${ }^{[51]}$ Our observations were further bolstered by a recently solved co-crystal structure of gefitinib in GAK showing the same high-energy water being displaced (Figure 9C). ${ }^{[52]}$

In summary, we have identified and optimized an island of activity within the ATP binding pocket of GAK by displacement of a high-energy water within the lipophilic pocket. The water molecules that occupy the ligand binding pocket prior to smallmolecule binding to a protein pocket play a significant role and can be considered as principal source of binding energy. These water molecules occupy certain hydration sites inside the pocket and are either energetically favourable or unfavourable in comparison to the bulk water. If the total energy of a hydration site is positive e.g. it is unfavourable, the replacement of this water will result in a binding affinity boost. A hydration site may be high in energy for multiple reasons, for example if a water is not able to form hydrogen bonds within the site enthalpic penalty results. Entropic penalty can exist when degrees of freedom are unfavourable for water compared to bulk waters. It is also common that a pocket water is transformed to be unfavourable if it is trapped or the degrees of freedom are limited when a small molecule is introduced to the binding site.
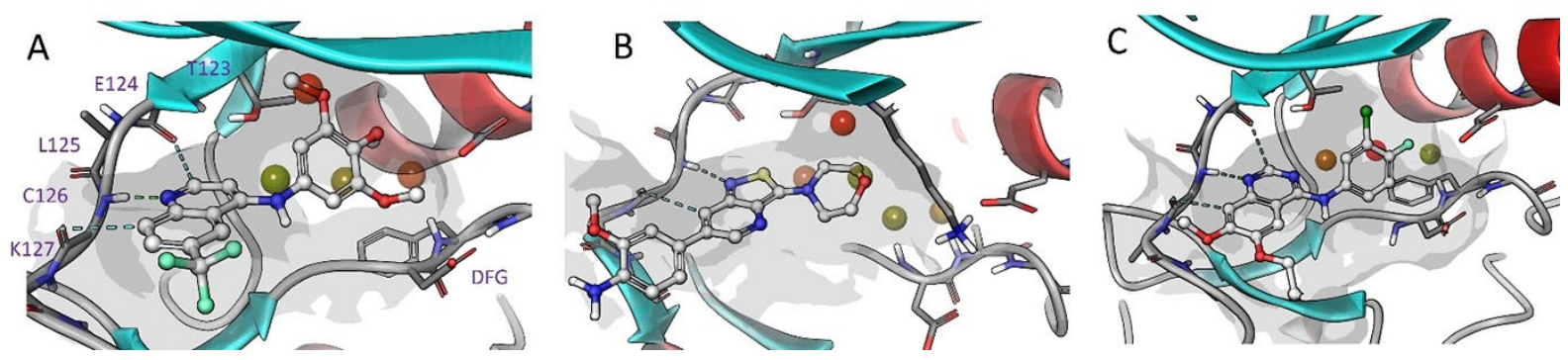

Figure 9. Selected WaterMap hydration sites overlaid with of A) 1 docked (PDB ID: 5Y80), B) JMC 2015-12 g retained at adenosine binding site of GAK (PDB ID: $4 Y 8 D$ ) and C) Gefitinib retained at adenosine binding site (PDB ID: 5Y80). 
In this study we have used WaterMap from Schrödinger to conduct hydration site analysis for family NAK kinases in order to explain ligand affinity further than simple crude scoring functions used in straightforward docking can achieve. ${ }^{[2,53-56]}$ The WaterMap software conducts statistical mechanics based on short molecular dynamics. This simulation describes the thermodynamic properties to estimate the energies of the hydration sites. This estimation is usually computed for the pocket without ligand to evaluated possible hydrations sites but can be also calculated with ligand. However, such short simulations keeping the protein rigid is highly dependent on the conformation of the protein and results are less valid in the case of arbitrary changes in protein conformations. Fortunately, the case of the NAK family kinases is well suited for hydration site analysis thus binding conformations are mapped by several high-resolution $x$-ray structures resulting in good overall convergence of the ligand dockings.

This method can be used to further optimize GAK inhibitors for potential in vitro and in vivo usage. ${ }^{[20,57]}$ Extension of this model to other NAK family members or more distantly related kinases could lead to computational models that predict wider kinome selectivity.

\section{Experimental Section}

\section{Modelling}

Molecular modelling: Molecular modelling was performed using Schrödinger Maestro software package (Small-Molecule Drug Discovery Suite 2018-4, Schrödinger, LLC, New York, NY, 2018) Prior to docking simulations structures of small molecules were prepared using and the LigPrep module of Schrodinger suite employing OPLS3e force field. ${ }^{[55]}$ In the case of GAK and other NAK family kinases there are a number of co-crystal structures available representing various ligand binding conformations, showing flexibility in the position of so-called the p-loop and C-helix region. Suitable docking templates were searched using LPDB module of Schrödinger package and carrying out visual inspection of available experimental structures with assistance of LiteMol plug-in available at website of UniProt database. Selected coordinates (PDB IDs: $4 \mathrm{Y} 8 \mathrm{D}$ and $5 \mathrm{Y} 7 \mathrm{Z})$ have been co-crystallized with at resolution of $2.1 \AA$ and $2.5 \AA$ respectively with a small molecule inhibitors. ${ }^{[26,52]}$ The PDB structure of GAK was $\mathrm{H}$-bond optimized and minimized using standard protein preparation procedure of Schrödinger suite. The ligand docking was performed using SP settings of Schrodinger docking protocol with softened vdw potential (scaling 0.6 ). In order to improve convergence of docking poses a hydrogen bond constraint to mainchain $\mathrm{NH}$ of hinge residue was required, as experimentally observed in the case of quinoline/quinolizine scaffolds (for example NH of $\mathrm{C} 126$ in the case of GAK). The grid box was centered using coordinate center of the core structure of corresponding x-ray ligand as template. Graphical illustrations were generated using, Maestro, and PyMOL software of Schrödinger.

Hydration site analysis: Hydration site analysis calculated with WaterMap (Schrödinger Release 2018-4: WaterMap, Schrödinger, LLC, New York, NY, 2018.). The structure of GAK (PDB ID: 4Y8D and $5 Y 7 Z$ ) was prepared with Protein Preparation Wizard (as above). ${ }^{[27,52]}$ Water molecules were analysed within $6 \AA$ from the docked ligand, and the 2 ns simulation was conducted with OPLS3e force field. ${ }^{[55]}$

\section{Biology}

Cellular NanoBRET target engagement assay: Screening was performed as previously described. ${ }^{[17]}$ Briefly, the $\mathrm{N}$-terminal Nano Luciferase/GAK fusion (NL-GAK) was encoded in pFN31K expression vector, including flexible Gly-Ser-Ser-Gly linkers between NL and GAK (Promega Madison, WI, USA). ${ }^{1}$ For cellular NanoBRET target engagement experiments, the NL-GAK fusion construct was diluted with carrier DNA-pGEM-3Zf(-) (Promega, Madison, WI, USA) at a mass ratio of $1: 10$ (mass/mass), prior to adding FuGENE HD (Promega). DNA:FuGENE complexes were formed at a ratio of $1: 3$ ( $\mu \mathrm{gDNA} / \mu \mathrm{L}$ FuGENE HD) according to the manufacturer's protocol (Promega). The resulting transfection complex (1 part, volume) was then gently mixed with 20 parts $(\mathrm{v} / \mathrm{v})$ of HEK-293 cells (ATCC) suspended at a density of $2 \times 10^{5}$ cells $/ \mathrm{mL}$ in DMEM (Gibco) $+10 \%$ FBS (Seradigm/VWR) followed by incubation $\left(37^{\circ} \mathrm{C} / 5 \% \mathrm{CO}_{2}\right)$ for 24 hours. After 24 hours HEK293 NL-GAK transfected cells were detached from flasks ( $0.05 \%$ Trypsin-EDTA or TrypLE) (Gibco) and re-suspended at a concentration of $2 \times 10^{5}$ cells $/ \mathrm{mL}$ in Opti-MEM media (Gibco).

Cellular nanoBRET assays were performed in Non-Binding Surface $\left(\mathrm{NBS}^{\mathrm{TM}}\right)$ /white, 96 -well plates (Corning) by addition of $1.7 \times$ $10^{4}$ cells/well $(85 \mu \mathrm{L})$. NanoBRET Tracer 5 (Promega) was used at a final concentration of $0.25 \mu \mathrm{M}$ as previously evaluated in a titration experiment. A total of $5 \mu \mathrm{L} /$ well $(20 \times$ working stock of nanoBRET Tracer $5[5 \mu \mathrm{M}]$ ) was added to all wells, except the "no tracer" control wells to which $5 \mu \mathrm{L} /$ well of tracer dilution buffer alone was added. All inhibitors were prepared initially as concentrated stock solutions in $100 \%$ DMSO (Sigma). A total of $10 \mu \mathrm{L} /$ well of the $10 \times$ chemical inhibitor stock solutions (final assay concentration $1 \%$ DMSO) were added. For "no compound" and "no tracer" control wells, a total of $10 \mathrm{~L} /$ well of Opti-MEM plus DMSO $(9 \mu \mathrm{L}$ was added (final concentration $1 \%$ DMSO)). 96 well plates containing cells with nanoBRET Tracer 5 and inhibitors $(100 \mu \mathrm{L}$ total volume per well) were equilibrated $\left(37^{\circ} \mathrm{C} / 5 \% \mathrm{CO}_{2}\right)$ for 2 hours. To measure nanoBRET signal, nanoBRET NanoGlo substrate at a ratio of 1:166 to OptiMEM media in combination with extracellular NanoLuc Inhibitor diluted 1:500 $(10 \mu \mathrm{L}$ [30 mM stock] per $5 \mathrm{~mL}$ Opti-MEM plus substrate) were combined to create a $3 \times$ stock. A total of $50 \mu \mathrm{L}$ of the $3 \times$ substrate/extracellular NanoLuc inhibitor were added to each well. The plates were read within $15 \mathrm{~min}$ (GloMax Discover luminometer, Promega) equipped with $450 \mathrm{nM}$ BP filter (donor) and $600 \mathrm{nM}$ LP filter (acceptor), using $0.3 \mathrm{~s}$ integration time instrument utilizing the "nanoBRET 618 " protocol.

Analysis of Inhibitors were screened at eight concentrations were evaluated in competition with NanoBRET Tracer 5 in HEK293 cells transiently expressing GAK. Prior to curve fitting, the average BRET ratio for "no tracer" (Opti-MEM + DMSO only) wells was subtracted from all experimental inhibitor well BRET ratio values and converted to mBRET units $(\times 1000)$. Additional normalization of the NanoBRET assay data was performed by converting experimental values for respective concentrations of experimental inhibitors to relative percent control values (no compound [Opti-MEM+DMSO + Tracer 5 only] wells $=100 \%$ Control, no tracer [Opti-MEM+DMSO] wells $=0 \%$ control). The data was normalized to $0 \%$ and $100 \%$ inhibition control values and fitted to a sigmoidal dose-response binding curve in GraphPad Software (version 7, La Jolla, CA, USA). Compounds that demonstrated $<10 \%$ Inhibition at $5 \mu \mathrm{M}$ were reported as no curve and compounds that showed $10 \%<x<50 \%$ Inhibition at $5 \mu \mathrm{M}$ were reported as \% inhibition. Compounds greater than $50 \%$ were reported as an $\mathrm{IC}_{50}$ value.

Ligand binding displacement assays: Screening was performed as previously described, ${ }^{[17]}$ Briefly, inhibitor binding was determined using a binding-displacement assay, which measures the ability of inhibitors to displace a fluorescent tracer compound from the ATP 
binding site of the kinase domain. Inhibitors were dissolved in DMSO and dispensed as 16-point, $2 \mathrm{~V}$ serial dilutions in duplicate into black multiwell plates (Greiner). Each well contained either 0.5 or $1 \mathrm{nM}$ biotinylated kinase domain protein ligated to streptavidinTb-cryptate (Cisbio), 12.5 or $25 \mathrm{nM}$ Kinase Tracer 236 (ThermoFisher Scientific), $10 \mathrm{mM}$ HEPES pH 7.5, $150 \mathrm{mM} \mathrm{NaCl}, 2 \mathrm{mM}$ DTT, $0.01 \%$ BSA, $0.01 \%$ Tween-20. Final assay volume for each data point was $5 \mathrm{~mL}$, and final DMSO concentration was $1 \%$. The kinase domain proteins were expressed in E. coli as a fusion with a C-terminal AVI tag (vector pNIC-Bio3, NCBI reference JN792439) which was biotinylated by co-expressed BirA, and purified using the same methods as used previously. ${ }^{[17]}$ After setting up the assay plate it was incubated at room temperature for 1.5 hours and then read using a TR-FRET proto Residue ranges were AAK1: 31-396, BMP2 K: 38-345, GAK: 12-347, STK16: 13-305 col on a PheraStarFS plate reader (BMG Labtech). The data were normalized to $0 \%$ and $100 \%$ inhibition control values and fitted to a four parameter doseresponse binding curve in GraphPad Software (version 7, La Jolla, CA, USA). The determined $I C_{50}$ values were converted into $K_{i}$ values using the Cheng-Prusoff equation and the concentration and $K_{d}$ values for the tracer (previously determined). Constructs used: AAK1 - AAKA-p051; BMPK2 K - BMP2KA-p031; GAK - GAKA-p059; STK16 - STK16 A-p016. ${ }^{[17]}$

\section{Chemistry}

$X$-ray crystallography: Single-crystal x-ray diffraction analyses of 13 , 14, 25, 27 and 29 were performed using a Rigaku FRE + equipped with VHF Varimax confocal mirrors and an AFC12 goniometer and HyPix 6000 hybrid pixel detector equipped with an Oxford Cryosystems low temperature apparatus operating at $T=100(2) \mathrm{K}$. CrysAlisPro ${ }^{[58]}$ was used to record images. CrysAlisPro was used to process all data and apply empirical absorption corrections and unit cell parameters were refined against all data. The structures were solved by intrinsic phasing using SHELXT ${ }^{[59]}$ and refined on Fo2 by full-matrix least-squares refinements using SHELXL ${ }^{[00]}$ as implemented within OLEX2. ${ }^{[61]}$ All non-hydrogen atoms were refined with anisotropic displacement parameters and hydrogen atoms were added at calculated positions except those attached to heteroatoms which were located from the difference map. All hydrogen atoms were refined using a riding model with isotropic displacement parameters based on the equivalent isotropic displacement parameter $\left(U_{\text {eq }}\right)$ of the parent atom. Figures were produced using OLEX2. The data for 14 were processed as a 2componant non-merohedral twin with the second component rotated $-179.8006^{\circ}$ around $[-0.01-0.290 .96]$ (reciprocal) or [0.00 0.001 .00 ] (direct) lattice vectors. The data for 29 were processed as an inversion twin. Solvent masking was applied to the data for 13 and 25 to eliminate the electronic contribution equivalent to 1.5 and 1 molecules of water, respectively. CCDC 1982229-1982230, 1982232-1982234 contain the supplementary crystallographic data for this paper. These data are provided free of charge by The Cambridge Crystallographic Data Centre

Mass spectrometry method: Samples were analysed with a ThermoFisher Q Exactive HF-X (ThermoFisher, Bremen, Germany) mass spectrometer coupled with a Waters Acquity H-class liquid chromatograph system. Samples were introduced via a heated electrospray source (HESI) at a flow rate of $0.6 \mathrm{~mL} / \mathrm{min}$. Electrospray source conditions were set as: spray voltage $3.0 \mathrm{kV}$, sheath gas (nitrogen) $60 \mathrm{arb}$, auxiliary gas (nitrogen) $20 \mathrm{arb}$, sweep gas (nitrogen) 0 arb, nebulizer temperature 375 degrees $C$, capillary temperature 380 degrees $\mathrm{C}, \mathrm{RF}$ funnel $45 \mathrm{~V}$. The mass range was set to $150-2000 \mathrm{~m} / \mathrm{z}$. All measurements were recorded at a resolution setting of 120000 .
Separations were conducted on a Waters Acquity UPLC BEH C18 column $(2.1 \times 50 \mathrm{mM}, 1.7 \mu \mathrm{M}$ particle size $)$. LC conditions were set at $100 \%$ water with $0.1 \%$ formic acid (A) ramped linearly over 9.8 mins to $95 \%$ acetonitrile with $0.1 \%$ formic acid (B) and held until 10.2 mins. At 10.21 mins the gradient was switched back to $100 \% \mathrm{~A}$ and allowed to re-equilibrate until 11.25 mins. Injection volume for all samples was $3 \mu \mathrm{L}$.

Xcalibur (ThermoFisher, Breman, Germany) was used to analyse the data. Solutions were analysed at $0.1 \mathrm{mg} / \mathrm{mL}$ or less based on responsiveness to the ESI mechanism. Molecular formula assignments were determined with Molecular Formula Calculator ( $v$ 1.2.3). All observed species were singly charged, as verified by unit $\mathrm{m} / \mathrm{z}$ separation between mass spectral peaks corresponding to the ${ }^{12} \mathrm{C}$ and ${ }^{13} \mathrm{C}^{12} \mathrm{C}_{\mathrm{c}-1}$ isotope for each elemental composition.

General procedure for the synthesis of 4-anilinoquin(az)olines: 4chloroquin(az)oline derivative (1.0 equiv) and aniline derivative (1.1 equiv) were suspended in ethanol $(10 \mathrm{~mL})$ and refluxed for $18 \mathrm{~h}$. The crude mixture was purified by flash chromatography using EtOAc/hexane followed by 1-5\% methanol in EtOAc; After solvent removal under reduced pressure, the product was obtained as a solid or recrystallized from ethanol/water. Compounds 1-4 were prepared as previously described. ${ }^{[17]}$

3-((6-(Trifluoromethyl)quinolin-4-yl)amino)phenol (5) was obtained as a mustard solid (114 mg, $0.376 \mathrm{mmol}, 58 \%)$. m.p. 166$168^{\circ} \mathrm{C} ;{ }^{1} \mathrm{H}$ NMR $\left(400 \mathrm{MHz},\left[\mathrm{D}_{6}\right.\right.$ ]DMSO): $\delta=11.09(\mathrm{~s}, 1 \mathrm{H}), 10.05(\mathrm{~s}, 1 \mathrm{H})$, $9.32(\mathrm{~s}, 1 \mathrm{H}), 8.56(\mathrm{~d}, J=6.6 \mathrm{~Hz}, 1 \mathrm{H}), 8.39-8.11(\mathrm{~m}, 2 \mathrm{H}), 7.32(\mathrm{t}, J=$ $8.0 \mathrm{~Hz}, 1 \mathrm{H}), 7.13-6.61(\mathrm{~m}, 4 \mathrm{H}) .{ }^{13} \mathrm{C}$ NMR $\left(100 \mathrm{MHz},\left[\mathrm{D}_{6}\right] \mathrm{DMSO}\right): \delta=$ $158.8,154.3,145.5,142.0,138.3,130.6,128.4(d, J=3.5 \mathrm{~Hz}), 126.3(\mathrm{q}$, $J=32.7 \mathrm{~Hz}), 125.3,123.4,122.5(\mathrm{~d}, J=5.2 \mathrm{~Hz}), 117.0,115.1,114.3$, 111.8, 101.4. HRMS $\mathrm{m} / \mathrm{z}[\mathrm{M}+\mathrm{H}]^{+}$calcd for $\mathrm{C}_{16} \mathrm{H}_{12} \mathrm{~N}_{2} \mathrm{OF}_{3}: 305.0902$, found 305.0892 , LC $t_{\mathrm{R}}=3.38 \mathrm{~min},>98 \%$ purity.

$\mathrm{N}$-(3-Nitrophenyl)-6-(trifluoromethyl)quinolin-4-amine

(179 mg, $0.538 \mathrm{mmol}, 83 \%)^{1} \mathrm{H}$ NMR (400 MHz, [D $\mathrm{D}_{6}$ DMSO): $\delta=11.84$ (s, 1H), 9.59-9.33 (m, 1H), $8.69(\mathrm{~d}, J=7.0 \mathrm{~Hz}, 1 \mathrm{H}), 8.38$ (dd, $J=4.5$, $2.4 \mathrm{~Hz}, 2 \mathrm{H}), 8.32(\mathrm{dd}, J=9.0,1.7 \mathrm{~Hz}, 1 \mathrm{H}), 8.24(\mathrm{ddd}, J=8.3,2.3$, $1.0 \mathrm{~Hz}, 1 \mathrm{H}), 8.02(\mathrm{ddd}, J=8.0,2.1,1.0 \mathrm{~Hz}, 1 \mathrm{H}), 7.86(\mathrm{t}, J=8.1 \mathrm{~Hz}, 1 \mathrm{H})$, $7.10(\mathrm{~d}, J=7.0 \mathrm{~Hz}, 1 \mathrm{H}) .{ }^{13} \mathrm{C}$ NMR $\left(100 \mathrm{MHz},\left[\mathrm{D}_{6}\right] \mathrm{DMSO}\right): \delta=155.2$, 148.6, 144.6, 140.3, 138.4, 131.4 (d, $J=17.2 \mathrm{~Hz}), 129.4(\mathrm{~d}, J=3.4 \mathrm{~Hz})$, $127.8,127.0(q, J=32.9 \mathrm{~Hz}), 125.1,123.0(\mathrm{q}, J=4.1 \mathrm{~Hz}), 122.4,122.0$ (d, $J=26.5 \mathrm{~Hz}$ ), 120.0, 117.1, 101.6. HRMS $\mathrm{m} / \mathrm{z}[\mathrm{M}+\mathrm{H}]^{+}$calcd for $\mathrm{C}_{16} \mathrm{H}_{11} \mathrm{~N}_{3} \mathrm{O}_{2} \mathrm{~F}_{3}$ : 334.0803 , found 334.0793 , LC $t_{\mathrm{R}}=3.78 \mathrm{~min},>98 \%$ purity.

$N^{1}$-(6-(Trifluoromethyl)quinolin-4-yl)benzene-1,3-diamine (7) 6 (150 $\mathrm{mg}$ ) was treated with palladium on carbon under hydrogen for $18 \mathrm{~h}$ and purified by flash chromatography using EtOAc/hexane followed by $2 \%$ methanol in EtOAc. The solvent was removed under reduced pressure, the product was obtained as a dark yellow solid (94 mg, $0.311 \mathrm{mmol}, 69 \%)$. ${ }^{1} \mathrm{H}$ NMR $\left(400 \mathrm{MHz},\left[\mathrm{D}_{6}\right] \mathrm{DMSO}\right): \delta=$ $10.79(\mathrm{~s}, 1 \mathrm{H}), 8.86-8.72(\mathrm{~m}, 1 \mathrm{H}), 8.47(\mathrm{~d}, J=6.9 \mathrm{~Hz}, 1 \mathrm{H}), 8.09(\mathrm{dd}, J=$ 8.5, 1.2 Hz, 1H), 7.98 (ddd, $J=8.4,6.9,1.2 \mathrm{~Hz}, 1 \mathrm{H}$ ), 7.75 (ddd, $J=8.4$, $6.9,1.2 \mathrm{~Hz}, 1 \mathrm{H}), 7.18(\mathrm{t}, J=8.0 \mathrm{~Hz}, 1 \mathrm{H}), 6.78(\mathrm{~d}, J=6.9 \mathrm{~Hz}, 1 \mathrm{H}), 6.71-$ $6.38(\mathrm{~m}, 3 \mathrm{H}), 5.48(\mathrm{~s}, 2 \mathrm{H}) .{ }^{13} \mathrm{C}$ NMR $(100 \mathrm{MHz}$, [D 6 DMSO): $\delta=154.8$, 150.4, 142.6, 138.7, 137.8, 133.6, 130.2, 126.7, 123.6, 120.5, 117.0, 113.0, 112.1, 110.2, 99.9. HRMS $\mathrm{m} / \mathrm{z}[\mathrm{M}+\mathrm{H}]^{+}$calcd for $\mathrm{C}_{16} \mathrm{H}_{13} \mathrm{~N}_{3} \mathrm{~F}_{3}$ : 304.1062 , found 304.1051 , LC $t_{\mathrm{R}}=3.20 \mathrm{~min},>98 \%$ purity.

${ }^{1} N,{ }^{1} N$-Dimethyl-3- $N$-[6-(trifluoromethyl)quinolin-4-yl]benzene-1,3diamine (8) was obtained as a dark yellow solid (163 mg, $0.492 \mathrm{mmol}, 76 \%)$. m.p. decomp $>160^{\circ} \mathrm{C} ;{ }^{1} \mathrm{H}$ NMR $\left(400 \mathrm{MHz},\left[\mathrm{D}_{6}\right]\right.$ DMSO): $\delta=11.37(\mathrm{~s}, 1 \mathrm{H}), 9.36(\mathrm{dt}, J=1.9,1.0 \mathrm{~Hz}, 1 \mathrm{H}), 8.55(\mathrm{~d}, J=$ $7.1 \mathrm{~Hz}, 1 \mathrm{H}), 8.46-8.08(\mathrm{~m}, 2 \mathrm{H}), 7.45-7.25(\mathrm{~m}, 1 \mathrm{H}), 6.87(\mathrm{~d}, J=7.1 \mathrm{~Hz}$ $1 \mathrm{H}), 6.86-6.75(\mathrm{~m}, 2 \mathrm{H}), 6.76-6.60(\mathrm{~m}, 1 \mathrm{H}), 2.94(\mathrm{~s}, 6 \mathrm{H}) .{ }^{13} \mathrm{C} N M R$ (101 MHz, [D $\mathrm{D}_{6}$ DMSO): $\delta=155.6,151.6,143.8,140.3,137.5,130.3$, $129.2(\mathrm{~d}, J=3.4 \mathrm{~Hz}), 126.6(\mathrm{q}, J=32.7 \mathrm{~Hz}), 125.1,122.6(\mathrm{q}, J=4.1 \mathrm{~Hz})$, 
$121.9,116.6,112.3,111.6,108.7,101.2,40.0$ (s, 2 C). HRMS $m / z[M+$ $\mathrm{H}]^{+}$calcd for $\mathrm{C}_{18} \mathrm{H}_{17} \mathrm{~N}_{3} \mathrm{~F}_{3}: 332.1375$, found 332.1366 , $\mathrm{LC} t_{\mathrm{R}}=4.02 \mathrm{~min}$, $>98 \%$ purity.

$\mathrm{N}$-(3-Nitrophenyl)quinolin-4-amine (9) was obtained as a yellow solid (217 mg, $0.816 \mathrm{mmol}, 89 \%)$. m.p. $>250{ }^{\circ} \mathrm{C} ;{ }^{1} \mathrm{H}$ NMR $(400 \mathrm{MHz}$, [D $\mathrm{D}_{6}$ ]DMSO): $\delta=11.39(\mathrm{~s}, 1 \mathrm{H}), 8.94(\mathrm{dd}, J=8.6,1.2 \mathrm{~Hz}, 1 \mathrm{H}), 8.61(\mathrm{~d}$, $J=6.9 \mathrm{~Hz}, 1 \mathrm{H}), 8.38(\mathrm{t}, J=2.2 \mathrm{~Hz}, 1 \mathrm{H}), 8.22(\mathrm{ddd}, J=8.3,2.3,1.0 \mathrm{~Hz}$, $1 \mathrm{H}), 8.17(\mathrm{dd}, J=8.6,1.2 \mathrm{~Hz}, 1 \mathrm{H}), 8.08-8.00(\mathrm{~m}, 2 \mathrm{H}), 7.87-7.81(\mathrm{~m}$, $2 \mathrm{H}), 7.04(\mathrm{~d}, J=6.8 \mathrm{~Hz}, 1 \mathrm{H}) .{ }^{13} \mathrm{C}$ NMR $\left(101 \mathrm{MHz},\left[\mathrm{D}_{6}\right] \mathrm{DMSO}\right): \delta=$ $154.6,148.6,143.2,138.9,138.4,134.0,131.4,131.2,127.3,124.0$, 121.5, 120.4, 119.8, 117.6, 100.4. HRMS $\mathrm{m} / \mathrm{z}[\mathrm{M}+\mathrm{H}]^{+}$calcd for $\mathrm{C}_{15} \mathrm{H}_{12} \mathrm{~N}_{3} \mathrm{O}_{2}: 266.0930$, found 266.0920 , LC $t_{\mathrm{R}}=2.97 \mathrm{~min},>98 \%$ purity.

$\boldsymbol{N}^{1}, \boldsymbol{N}^{1}$-Dimethyl- $\boldsymbol{N}^{3}$-(quinolin-4-yl)benzene-1,3-diamine (10) was obtained as a dark yellow solid (188 mg, $0.715 \mathrm{mmol}, 78 \%)$ m.p. $>250^{\circ} \mathrm{C} ;{ }^{1} \mathrm{H}$ NMR $\left(400 \mathrm{MHz},\left[\mathrm{D}_{6}\right] \mathrm{DMSO}\right): \delta=10.98(\mathrm{~s}, 1 \mathrm{H}), 8.85(\mathrm{dd}$, $J=8.7,1.2 \mathrm{~Hz}, 1 \mathrm{H}), 8.47(\mathrm{~d}, J=7.0 \mathrm{~Hz}, 1 \mathrm{H}), 8.11(\mathrm{dd}, J=8.6,1.2 \mathrm{~Hz}$, $1 \mathrm{H}), 8.00$ (ddd, $J=8.4,6.9,1.2 \mathrm{~Hz}, 1 \mathrm{H}$ ), 7.77 (ddd, $J=8.3,6.9,1.2 \mathrm{~Hz}$, $1 \mathrm{H}), 7.35(\mathrm{td}, J=7.8,0.9 \mathrm{~Hz}, 1 \mathrm{H}), 6.80(\mathrm{~d}, J=7.0 \mathrm{~Hz}, 1 \mathrm{H}), 6.78-6.44$ (m, 3H), $2.94(\mathrm{~s}, 6 \mathrm{H}) .{ }^{13} \mathrm{C}$ NMR (101 MHz, [D $]$ DMSO): $\delta=155.1,151.6$, $142.4,138.3,137.9,133.7,130.2,126.8,123.7,120.2,117.0,112.5$, 111.3, 109.0, 100.0, $40.0(\mathrm{~s}, 2 \mathrm{C})$. HRMS $\mathrm{m} / \mathrm{z}[\mathrm{M}+\mathrm{H}]^{+}$calcd for $\mathrm{C}_{17} \mathrm{H}_{18} \mathrm{~N}_{3}: 264.1501$, found 264.1493 , LC $t_{\mathrm{R}}=3.09 \mathrm{~min},>98 \%$ purity.

(3-\{[6-(Trifluoromethyl)quinolin-4-yl]amino\}phenyl)methanol (11) was obtained as a light yellow solid (151 $\mathrm{mg}, 0.473 \mathrm{mmol}, 73 \%$ ). m.p. $152-154^{\circ} \mathrm{C} ;{ }^{1} \mathrm{H}$ NMR $\left(400 \mathrm{MHz},\left[\mathrm{D}_{6}\right] \mathrm{DMSO}\right): \delta=10.94(\mathrm{~s}, 1 \mathrm{H})$, $9.28(\mathrm{~d}, J=1.9 \mathrm{~Hz}, 1 \mathrm{H}), 8.57(\mathrm{~d}, J=6.6 \mathrm{~Hz}, 1 \mathrm{H}), 8.26(\mathrm{~d}, J=8.9 \mathrm{~Hz}$, $1 \mathrm{H}), 8.19(\mathrm{dd}, J=8.9,1.8 \mathrm{~Hz}, 1 \mathrm{H}), 7.49(\mathrm{t}, J=7.7 \mathrm{~Hz}, 1 \mathrm{H}), 7.43(\mathrm{t}, J=$ $1.8 \mathrm{~Hz}, 1 \mathrm{H}), 7.32(\mathrm{ddt}, J=10.4,7.6,1.2 \mathrm{~Hz}, 2 \mathrm{H}), 6.90(\mathrm{~d}, J=6.6 \mathrm{~Hz}$, $1 \mathrm{H}), 5.42(\mathrm{~s}, 1 \mathrm{H}), 4.57(\mathrm{~s}, 2 \mathrm{H}) .{ }^{13} \mathrm{C}$ NMR $\left(100 \mathrm{MHz},\left[\mathrm{D}_{6}\right] \mathrm{DMSO}\right): \delta=$ 153.6, 146.5, 144.7, 143.0, 137.6, 129.5, $128.0(\mathrm{~d}, J=2.7 \mathrm{~Hz}), 126.2(\mathrm{q}$, $J=32.7 \mathrm{~Hz}), 125.4,124.7,124.3,122.4,122.3(\mathrm{~d}, J=4.3 \mathrm{~Hz}), 122.3$, 117.3, 101.3, 62.4. HRMS $\mathrm{m} / \mathrm{z}[\mathrm{M}+\mathrm{H}]^{+}$calcd for $\mathrm{C}_{17} \mathrm{H}_{14} \mathrm{~N}_{2} \mathrm{OF}_{3}$ : 319.1058 , found 319.1048 , LC $t_{R}=3.26 \mathrm{~min},>98 \%$ purity.

(2-\{[6-(Trifluoromethyl)quinolin-4-yl]amino\}phenyl)methanol (12) was obtained as a grey/yellow solid (132 $\mathrm{mg}, 0.416 \mathrm{mmol}, 64 \%$ ). m.p. $120-122^{\circ} \mathrm{C} ;{ }^{1} \mathrm{H}$ NMR $\left(400 \mathrm{MHz},\left[\mathrm{D}_{6}\right] \mathrm{DMSO}\right): \delta=10.18(\mathrm{~s}, 1 \mathrm{H})$, $9.18(\mathrm{~s}, 1 \mathrm{H}), 8.48(\mathrm{~d}, J=6.1 \mathrm{~Hz}, 1 \mathrm{H}), 8.33-7.85(\mathrm{~m}, 2 \mathrm{H}), 7.84-7.56(\mathrm{~m}$, $1 \mathrm{H}), 7.56-6.93(\mathrm{~m}, 3 \mathrm{H}), 6.27(\mathrm{~d}, J=6.1 \mathrm{~Hz}, 1 \mathrm{H}), 5.33(\mathrm{~s}, 1 \mathrm{H}), 4.49(\mathrm{~s}$, 2H). ${ }^{13} \mathrm{C}$ NMR $\left(100 \mathrm{MHz},\left[\mathrm{D}_{6}\right.\right.$ ]DMSO): $\delta=152.9,148.9,145.7,139.2$, $135.3,128.4,128.2,127.5,127.0,126.9-126.4(\mathrm{~m}), 125.6(\mathrm{~d}, J=$ $4.9 \mathrm{~Hz}), 125.3,122.9,121.8(\mathrm{q}, J=4.3 \mathrm{~Hz}), 117.4,101.3,59.0$. HRMS $\mathrm{m} / \mathrm{z}[\mathrm{M}+\mathrm{H}]^{+}$calcd for $\mathrm{C}_{17} \mathrm{H}_{14} \mathrm{~N}_{2} \mathrm{OF}_{3}: 319.1058$, found 319.1048, LC $t_{\mathrm{R}}=3.24 \mathrm{~min},>98 \%$ purity.

6-Bromo- $\mathrm{N}$-(3-methoxyphenyl)quinolin-4-amine (13) was obtained as a a beige solid (151 mg, $0.458 \mathrm{mmol}, 74 \%)$. m.p. $188-190^{\circ} \mathrm{C} ;{ }^{1} \mathrm{H}$ NMR (400 MHz, [D $]$ DMSO): $\delta=11.07(\mathrm{~s}, 1 \mathrm{H}), 9.16(\mathrm{~d}, J=2.0 \mathrm{~Hz}, 1 \mathrm{H})$, $8.52(\mathrm{~d}, J=7.0 \mathrm{~Hz}, 1 \mathrm{H}), 8.17(\mathrm{dd}, J=9.0,2.0 \mathrm{~Hz}, 1 \mathrm{H}), 8.08(\mathrm{~d}, J=$ $9.0 \mathrm{~Hz}, 1 \mathrm{H}), 7.48(\mathrm{t}, J=8.4 \mathrm{~Hz}, 1 \mathrm{H}), 7.31-7.03(\mathrm{~m}, 2 \mathrm{H}), 7.00$ (ddd, $J=$ 8.3, 2.4, $1.0 \mathrm{~Hz}, 1 \mathrm{H}), 6.89(\mathrm{~d}, J=6.9 \mathrm{~Hz}, 1 \mathrm{H}), 3.81(\mathrm{~s}, 3 \mathrm{H}) .{ }^{13} \mathrm{C}$ NMR (100 MHz, [D 6 DMSO): $\delta={ }^{13} \mathrm{C}$ NMR (101 MHz, [D 6 ]DMSO): $\delta=160.3$, $153.9,143.0,138.2,137.4,136.6,130.8,126.2,122.5,119.8,118.6$, 117.1, 113.1, 110.9, 100.7, 55.4. HRMS $\mathrm{m} / \mathrm{z}[\mathrm{M}+\mathrm{H}]^{+}$calcd for $\mathrm{C}_{16} \mathrm{H}_{14} \mathrm{~N}_{2} \mathrm{BrO}$ : 329.0286 , found 329.0289 , LC $t_{\mathrm{R}}=3.63 \mathrm{~min},>98 \%$ purity.

3-((6-Bromoquinolin-4-yl)amino)phenol (14) was obtained as a yellow solid (138 mg, $0.437 \mathrm{mmol}, 71 \%)$. m.p. $>300^{\circ} \mathrm{C} ;{ }^{1} \mathrm{H}$ NMR (400 MHz, [D $\mathrm{D}_{6}$ DMSO): $\delta=11.00(\mathrm{~s}, 1 \mathrm{H}), 10.03(\mathrm{~s}, 1 \mathrm{H}), 9.14(\mathrm{~d}, J=$ $2.0 \mathrm{~Hz}, 1 \mathrm{H}), 8.51(\mathrm{~d}, J=7.0 \mathrm{~Hz}, 1 \mathrm{H}), 8.15(\mathrm{dd}, J=9.0,2.0 \mathrm{~Hz}, 1 \mathrm{H}), 8.06$ $(\mathrm{d}, J=9.0 \mathrm{~Hz}, 1 \mathrm{H}), 7.42-7.29(\mathrm{~m}, 1 \mathrm{H}), 7.10-6.66(\mathrm{~m}, 4 \mathrm{H}) .{ }^{13} \mathrm{C}$ NMR (100 MHz, $\left[\mathrm{D}_{6}\right.$ ]DMSO): $\delta=159.2,154.4,143.3,138.3,137.7,137.0$, $131.1,126.6,122.8,120.2,119.0,115.9,115.2,112.5,101.0$. HRMS m/
$z[M+\mathrm{H}]^{+}$calcd for $\mathrm{C}_{15} \mathrm{H}_{11} \mathrm{BrN}_{2} \mathrm{O}: 315.0132$, found 315.0124, $\mathrm{LC} t_{\mathrm{R}}=$ $3.01 \mathrm{~min},>98 \%$ purity.

$\mathrm{N}$-(3-Methoxyphenyl)quinolin-4-amine (15) was obtained as a grey solid $(191 \mathrm{mg}, 0.761 \mathrm{mmol}, 81 \%)$. m.p. $198-200^{\circ} \mathrm{C}$; ${ }^{1} \mathrm{H} \quad \mathrm{NMR}$ (400 MHz, [D $\mathrm{D}_{6}$ DMSO): $\delta=11.08(\mathrm{~s}, 1 \mathrm{H}), 8.88(\mathrm{dd}, J=8.6,1.2 \mathrm{~Hz}, 1 \mathrm{H})$, $8.50(\mathrm{~d}, J=7.0 \mathrm{~Hz}, 1 \mathrm{H}), 8.13(\mathrm{dd}, J=8.6,1.2 \mathrm{~Hz}, 1 \mathrm{H}$ ), 8.02 (ddd, $J=$ 8.4, 6.9, 1.2 Hz, $1 \mathrm{H}), 7.79$ (ddd, $J=8.4,6.9,1.2 \mathrm{~Hz}, 1 \mathrm{H}), 7.54-7.40(\mathrm{~m}$, $1 \mathrm{H}), 7.31-7.04(\mathrm{~m}, 2 \mathrm{H}), 7.04-6.89(\mathrm{~m}, 1 \mathrm{H}), 6.85(\mathrm{~d}, J=6.9 \mathrm{~Hz}, 1 \mathrm{H})$, 3.81 (s, 3H). ${ }^{13} \mathrm{C}$ NMR (100 MHz, [D $]$ DMSO): $\delta=160.3,154.9,142.6$, 138.4, 138.2, 133.8, 130.7, 127.0, 123.8, 120.2, 117.4, 117.1, 113.1, 111.2, 100.0, 55.4. HRMS $\mathrm{m} / \mathrm{z}[\mathrm{M}+\mathrm{H}]^{+}$calcd for $\mathrm{C}_{16} \mathrm{H}_{15} \mathrm{~N}_{2} \mathrm{O}$ : 251.1184 , found 251.1175 , LC $t_{R}=3.17 \mathrm{~min},>98 \%$ purity.

3-(Quinolin-4-ylamino)phenol (16) was obtained as a green/yellow solid (74 mg, $0.312 \mathrm{mmol}, 34 \%$ ). m.p. decomp. $>230^{\circ} \mathrm{C} ;{ }^{1} \mathrm{H}$ NMR (400 MHz, [D $\mathrm{D}_{6}$ DMSO): $\delta=10.97(\mathrm{~s}, 1 \mathrm{H}), 10.03(\mathrm{~s}, 1 \mathrm{H}), 8.84$ (dd, $J=$ 8.7, $1.1 \mathrm{~Hz}, 1 \mathrm{H}), 8.50(\mathrm{~d}, J=7.0 \mathrm{~Hz}, 1 \mathrm{H}), 8.11(\mathrm{dd}, J=8.5,1.2 \mathrm{~Hz}, 1 \mathrm{H})$, 8.01 (ddd, $J=8.4,6.9,1.2 \mathrm{~Hz}, 1 \mathrm{H}$ ), 7.77 (ddd, $J=8.3,6.9,1.2 \mathrm{~Hz}, 1 \mathrm{H}$ ), 7.48-7.19 (m, 1H), 6.91-6.80 (m, 3H). ${ }^{13} \mathrm{C}$ NMR $\left(100 \mathrm{MHz},\left[\mathrm{D}_{6}\right] \mathrm{DMSO}\right)$ : $\delta=158.8,155.0,142.5,138.2,138.0,133.8,130.6,126.9,123.8,120.1$, 117.1, 115.7, 114.7, 112.3, 99.9. HRMS $\mathrm{m} / \mathrm{z}[\mathrm{M}+\mathrm{H}]^{+}$calcd for $\mathrm{C}_{15} \mathrm{H}_{13} \mathrm{~N}_{2} \mathrm{O}: 237.1028$, found 237.1019, LC $t_{\mathrm{R}}=2.66 \mathrm{~min},>98 \%$ purity.

6-Methoxy-N-(3-methoxyphenyl)quinolin-4-amine (17) was obtained as a beige/yellow solid (148 mg, $0.527 \mathrm{mmol}, 68 \%$ ). m.p. 170-172 ${ }^{\circ} \mathrm{C} ;{ }^{1} \mathrm{H}$ NMR $\left(400 \mathrm{MHz},\left[\mathrm{D}_{6}\right] \mathrm{DMSO}\right): \delta=10.93(\mathrm{~s}, 1 \mathrm{H}), 8.41(\mathrm{~d}$, $J=6.9 \mathrm{~Hz}, 1 \mathrm{H}), 8.28(\mathrm{~d}, J=2.6 \mathrm{~Hz}, 1 \mathrm{H}), 8.06(\mathrm{~d}, J=9.3 \mathrm{~Hz}, 1 \mathrm{H}), 7.66$ (dd, J=9.2, $2.6 \mathrm{~Hz}, 1 \mathrm{H}), 7.52-7.40(\mathrm{~m}, 1 \mathrm{H}), 7.28-7.03(\mathrm{~m}, 2 \mathrm{H}), 6.99$ (ddd, $J=8.4,2.4,1.1 \mathrm{~Hz}, 1 \mathrm{H}), 6.84(\mathrm{~d}, J=6.8 \mathrm{~Hz}, 1 \mathrm{H}), 4.00(\mathrm{~s}, 3 \mathrm{H})$, 3.81 (s, 3H). ${ }^{13} \mathrm{C}$ NMR $\left(100 \mathrm{MHz},\left[\mathrm{D}_{6}\right] \mathrm{DMSO}\right): \delta=160.3,158.0,153.8$, $140.5,138.6,133.5,130.7,125.4,121.9,118.5,117.4,112.8,111.1$, 103.0, 99.8, 56.6, 55.4. HRMS $\mathrm{m} / \mathrm{z}[\mathrm{M}+\mathrm{H}]^{+}$calcd for $\mathrm{C}_{17} \mathrm{H}_{17} \mathrm{~N}_{2} \mathrm{O}_{2}$ : 281.1290, found 281.1281 , LC $t_{R}=3.58 \mathrm{~min},>98 \%$ purity.

3-((6-Methoxyquinolin-4-yl)amino)phenol (18) was obtained as a beige solid (78 mg, $0.294 \mathrm{mmol}, 38 \%)$. m.p. $>300^{\circ} \mathrm{C} ;{ }^{1} \mathrm{H}$ NMR (400 MHz, [D $]$ DMSO): $\delta=10.79(\mathrm{~s}, 1 \mathrm{H}), 9.99(\mathrm{~s}, 1 \mathrm{H}), 8.40(\mathrm{~d}, J=$ $6.9 \mathrm{~Hz}, 1 \mathrm{H}), 8.23(\mathrm{~d}, J=2.6 \mathrm{~Hz}, 1 \mathrm{H}), 8.04(\mathrm{~d}, J=9.3 \mathrm{~Hz}, 1 \mathrm{H}), 7.65(\mathrm{dd}$, $J=9.2,2.5 \mathrm{~Hz}, 1 \mathrm{H}), 7.39-7.29(\mathrm{~m}, 1 \mathrm{H}), 7.00-6.71(\mathrm{~m}, 4 \mathrm{H}), 3.99(\mathrm{~s}, 3 \mathrm{H})$. ${ }^{13} \mathrm{C}$ NMR (100 MHz, [D $]$ DMSO): $\delta=158.7,157.9,153.8,140.5,138.3$, 133.5, 130.6, 125.3, 121.9, 118.4, 115.7, 114.4, 112.3, 102.9, 99.6, 56.5. HRMS $\mathrm{m} / \mathrm{z}[\mathrm{M}+\mathrm{H}]^{+}$calcd for $\mathrm{C}_{16} \mathrm{H}_{15} \mathrm{~N}_{2} \mathrm{O}_{2}$ : 267.1134, found $267.1124, \mathrm{LC} t_{\mathrm{R}}=3.05 \mathrm{~min},>98 \%$ purity.

6-Methanesulfonyl- $N$-(3-methoxyphenyl)quinolin-4-amine (19) was obtained as a yellow solid (171 mg, $0.521 \mathrm{mmol}, 84 \%)$. m.p. 271-273 ${ }^{\circ} \mathrm{C} ;{ }^{1} \mathrm{H}$ NMR (400 MHz, [D $\mathrm{D}_{6}$ DMSO): $\delta=11.61(\mathrm{~s}, 1 \mathrm{H}), 9.55$ (d, $J=1.8 \mathrm{~Hz}, 1 \mathrm{H}), 8.59(\mathrm{~d}, J=7.0 \mathrm{~Hz}, 1 \mathrm{H}), 8.44(\mathrm{dd}, J=8.9,1.8 \mathrm{~Hz}, 1 \mathrm{H})$, $8.31(\mathrm{~d}, J=8.9 \mathrm{~Hz}, 1 \mathrm{H}), 7.54-7.45(\mathrm{~m}, 1 \mathrm{H}), 7.14-7.05(\mathrm{~m}, 2 \mathrm{H}), 7.03$ (ddd, $J=8.4,2.3,1.1 \mathrm{~Hz}, 1 \mathrm{H}), 6.95(\mathrm{~d}, J=7.0 \mathrm{~Hz}, 1 \mathrm{H}), 3.81(\mathrm{~s}, 3 \mathrm{H})$, $3.44(\mathrm{~s}, 3 \mathrm{H}) .{ }^{13} \mathrm{C}$ NMR $\left(100 \mathrm{MHz},\left[\mathrm{D}_{6}\right] \mathrm{DMSO}\right): \delta=160.4,155.6,144.4$, $140.7,138.7,138.0,130.8,130.4,124.9,121.8,117.1,116.8,113.3$, $110.9,101.5,55.4,43.5$. HRMS $m / z[M+H]^{+}$calcd for $\mathrm{C}_{17} \mathrm{H}_{17} \mathrm{~N}_{2} \mathrm{O}_{3} \mathrm{~S}$ : 329.0960 , found 329.0953 , LC $t_{R}=3.08 \mathrm{~min},>98 \%$ purity.

3-((6-(Methylsulfonyl)quinolin-4-yl)amino)phenol (20) was obtained as a yellow solid (98 mg, $0.312 \mathrm{mmol}, 50 \%)$. m.p. $>300^{\circ} \mathrm{C}$; ${ }^{1} \mathrm{H}$ NMR (400 MHz, [D $]$ DMSO): $\delta=11.51(\mathrm{~s}, 1 \mathrm{H}), 10.03(\mathrm{~s}, 1 \mathrm{H}), 9.51$ $(\mathrm{d}, J=1.8 \mathrm{~Hz}, 1 \mathrm{H}), 8.58(\mathrm{~d}, J=7.1 \mathrm{~Hz}, 1 \mathrm{H}), 8.43(\mathrm{dd}, J=8.9,1.8 \mathrm{~Hz}$, $1 \mathrm{H}), 8.28(\mathrm{~d}, J=8.9 \mathrm{~Hz}, 1 \mathrm{H}), 7.37(\mathrm{t}, J=8.3 \mathrm{~Hz}, 1 \mathrm{H}), 7.09-6.66(\mathrm{~m}, 4 \mathrm{H})$, $3.43(\mathrm{~s}, 3 \mathrm{H}) .{ }^{13} \mathrm{C}$ NMR $\left(100 \mathrm{MHz},\left[\mathrm{D}_{6}\right] \mathrm{DMSO}\right): \delta=158.8,155.6,144.2$, $140.7,138.6,137.8,130.7,130.4,124.9,121.8,116.8,115.4,114.9$, 112.0, 101.3, 43.5. HRMS $\mathrm{m} / \mathrm{z}[\mathrm{M}+\mathrm{H}]^{+}$calcd for $\mathrm{C}_{16} \mathrm{H}_{15} \mathrm{~N}_{2} \mathrm{O}_{3} \mathrm{~S}$ : 315.0803 , found 315.0796 , LC $t_{\mathrm{R}}=2.29 \mathrm{~min},>98 \%$ purity.

6-Bromo- $\mathrm{N}$-(3-nitrophenyl)quinolin-4-amine (21) was obtained as a beige solid (162 mg, $0.470 \mathrm{mmol}, 76 \%$ ). m.p. $290-292^{\circ} \mathrm{C} ;{ }^{1} \mathrm{H}$ NMR 
(400 MHz, [D 6 DMSO): $\delta=11.39(\mathrm{~s}, 1 \mathrm{H}), 9.23(\mathrm{~d}, J=2.0 \mathrm{~Hz}, 1 \mathrm{H}), 8.62$ $(\mathrm{d}, J=6.9 \mathrm{~Hz}, 1 \mathrm{H}), 8.36(\mathrm{t}, J=2.2 \mathrm{~Hz}, 1 \mathrm{H}), 8.30-8.15(\mathrm{~m}, 2 \mathrm{H}), 8.13(\mathrm{~d}$, $J=9.0 \mathrm{~Hz}, 1 \mathrm{H}), 8.00(\mathrm{ddd}, J=8.0,2.1,1.0 \mathrm{~Hz}, 1 \mathrm{H}), 7.84(\mathrm{t}, J=8.1 \mathrm{~Hz}$, $1 \mathrm{H}), 7.08(\mathrm{~d}, J=6.9 \mathrm{~Hz}, 1 \mathrm{H}) .{ }^{13} \mathrm{C}$ NMR $\left(100 \mathrm{MHz},\left[\mathrm{D}_{6}\right] \mathrm{DMSO}\right): \delta=$ 153.6, 148.6, 143.5, 138.6, 137.5, 136.7, 131.3, 131.2, 126.4, 122.6, 121.6, 120.2, 119.7, 119.0, 101.1. HRMS $\mathrm{m} / \mathrm{z}[\mathrm{M}+\mathrm{H}]^{+}$calcd for $\mathrm{C}_{15} \mathrm{H}_{11} \mathrm{~N}_{3} \mathrm{O}_{2} \mathrm{Br}$ : 344.0035, found 344.0032, LC $t_{\mathrm{R}}=3.48 \mathrm{~min},>98 \%$ purity.

1-N-(6-Bromoquinolin-4-yl)benzene-1,3-diamine (22) 21 (150 mg) was treated with palladium on carbon under hydrogen for $18 \mathrm{~h}$ and purified by flash chromatography using EtOAc/hexane followed by $2 \%$ methanol in EtOAc. The solvent was removed under reduced pressure, the product was obtained as a brown solid (129 mg, $0.410 \mathrm{mmol}, 94 \%)$. m.p. $280-282{ }^{\circ} \mathrm{C} ;{ }^{1} \mathrm{H}$ NMR (400 MHz, [D 6 ]DMSO): $\delta=11.06(\mathrm{~s}, 1 \mathrm{H}), 8.85(\mathrm{~d}, J=8.6 \mathrm{~Hz}, 1 \mathrm{H}), 8.58(\mathrm{~d}, J=6.9 \mathrm{~Hz}, 1 \mathrm{H})$ 8.16-8.00 (m, 2H), $7.81(\mathrm{t}, J=7.8 \mathrm{~Hz}, 1 \mathrm{H}), 7.57(\mathrm{t}, J=8.2 \mathrm{~Hz}, 1 \mathrm{H}), 7.34$ $(\mathrm{d}, J=6.0 \mathrm{~Hz}, 2 \mathrm{H}), 7.24(\mathrm{~d}, J=7.7 \mathrm{~Hz}, 1 \mathrm{H}), 6.89(\mathrm{~d}, J=6.9 \mathrm{~Hz}, 1 \mathrm{H}) .{ }^{13} \mathrm{C}$ NMR $\left(100 \mathrm{MHz},\left[\mathrm{D}_{6}\right] \mathrm{DMSO}\right): \delta=154.8,142.8,138.2,138.1,134.0$, 130.9, 127.2, 123.8, 123.6, 121.6, 120.2, 119.8, 117.6, 117.2, 100.0 . HRMS $m / z[M+H]^{+}$calcd for $\mathrm{C}_{15} \mathrm{H}_{13} \mathrm{BrN}_{3}$ : 314.0293, found 314.0293, $\mathrm{LC} t_{\mathrm{R}}=2.22 \mathrm{~min},>98 \%$ purity.

3-N-(6-Bromoquinolin-4-yl)-1-N,1-N-dimethylbenzene-1,3-diamine (23) was obtained as a yellow/mustard solid (144 mg, $0.421 \mathrm{mmol}$, $68 \%$ ). m.p. Decomp. $>280^{\circ} \mathrm{C}^{1}{ }^{1} \mathrm{H}$ NMR (400 MHz, [D 6 DMSO): $\delta=$ $10.99(\mathrm{~s}, 1 \mathrm{H}), 9.14(\mathrm{~d}, J=2.0 \mathrm{~Hz}, 1 \mathrm{H}), 8.48(\mathrm{~d}, J=6.9 \mathrm{~Hz}, 1 \mathrm{H}), 8.15(\mathrm{dd}$, $J=9.0,2.0 \mathrm{~Hz}, 1 \mathrm{H}), 8.07(\mathrm{~d}, J=9.0 \mathrm{~Hz}, 1 \mathrm{H}), 7.39-7.27(\mathrm{~m}, 1 \mathrm{H}), 6.84(\mathrm{~d}$, $J=7.0 \mathrm{~Hz}, 1 \mathrm{H}), 6.81-6.51(\mathrm{~m}, 3 \mathrm{H}), 2.94(\mathrm{~s}, 6 \mathrm{H}) .{ }^{13} \mathrm{C} \mathrm{NMR}(100 \mathrm{MHz}$, [D $]$ DMSO): $\delta=154.2,151.6,142.8,137.7,137.3,136.5,130.2,126.1$, 122.4, 119.7, 118.5, 112.2, 111.38, 108.7, 100.6, 39.98 (2 C, s). HRMS $\mathrm{m} / \mathrm{z}[\mathrm{M}+\mathrm{H}]^{+}$calcd for $\mathrm{C}_{17} \mathrm{H}_{17} \mathrm{~N}_{3} \mathrm{Br}$ : 342.0606, found 342.0597, LC $t_{\mathrm{R}}=$ $3.74 \min ,>98 \%$ purity.

\{3-[(6-Bromoquinolin-4-yl)amino]phenyl\}methanol (24) was obtained as a yellow/mustard solid (155 mg, $0.470 \mathrm{mmol}, 76 \%)$ m.p. 132-134 ${ }^{\circ} \mathrm{C} ;{ }^{1} \mathrm{H}$ NMR (400 MHz, [D 6 DMSO): $\delta=10.93(\mathrm{~s}, 1 \mathrm{H}), 9.13(\mathrm{~d}$ $J=2.0 \mathrm{~Hz}, 1 \mathrm{H}), 8.52(\mathrm{~d}, J=6.8 \mathrm{~Hz}, 1 \mathrm{H}), 8.14(\mathrm{dd}, J=9.0,1.9 \mathrm{~Hz}, 1 \mathrm{H})$, $8.06(\mathrm{~d}, J=9.0 \mathrm{~Hz}, 1 \mathrm{H}), 7.51(\mathrm{t}, J=7.7 \mathrm{~Hz}, 1 \mathrm{H}), 7.45-7.11(\mathrm{~m}, 3 \mathrm{H}), 6.85$ $(\mathrm{d}, J=6.8 \mathrm{~Hz}, 1 \mathrm{H}), 5.41(\mathrm{~s}, 1 \mathrm{H}), 4.58(\mathrm{~s}, 2 \mathrm{H}) .{ }^{13} \mathrm{C} \mathrm{NMR}\left(100 \mathrm{MHz},\left[\mathrm{D}_{6}\right]\right.$ DMSO): $\delta=153.5,144.8,143.6,138.1,137.1,136.2,129.6,126.1$, $125.1,123.1,122.7,119.7,118.8,100.5,62.3$. HRMS $m / z[M+H]^{+}$ calcd for $\mathrm{C}_{16} \mathrm{H}_{14} \mathrm{~N}_{2} \mathrm{OBr}$ : 329.0289, found 329.0283, LC $t_{\mathrm{R}}=4.20 \mathrm{~min}$, $>98 \%$ purity.

$\mathrm{N}$-(2H-1,3-Benzodioxol-5-yl)-6-bromoquinolin-4-amine (25) was obtained as a green solid (144 mg, $0.421 \mathrm{mmol}, 68 \%)$. m.p. 240$242{ }^{\circ} \mathrm{C} ;{ }^{1} \mathrm{H}$ NMR (400 MHz, [D 6 DMSO): $\delta=11.00(\mathrm{~s}, 1 \mathrm{H}), 9.14(\mathrm{~d}, J=$ $2.0 \mathrm{~Hz}, 1 \mathrm{H}), 8.49(\mathrm{~d}, J=7.0 \mathrm{~Hz}, 1 \mathrm{H}), 8.15(\mathrm{dd}, J=9.0,2.0 \mathrm{~Hz}, 1 \mathrm{H}), 8.06$ $(\mathrm{d}, J=9.0 \mathrm{~Hz}, 1 \mathrm{H}), 7.44-7.00(\mathrm{~m}, 2 \mathrm{H}), 6.93(\mathrm{dd}, J=8.2,2.1 \mathrm{~Hz}, 1 \mathrm{H})$, $6.73(\mathrm{~d}, J=6.9 \mathrm{~Hz}, 1 \mathrm{H}), 6.13(\mathrm{~s}, 2 \mathrm{H}) .{ }^{13} \mathrm{C}$ NMR (100 MHz, [D $]$ DMSO): $\delta=154.5,148.2,146.6,142.8,137.3,136.5,130.6,126.2,122.4,119.7$, $119.2,118.4,108.9,106.9,101.9,100.4$. HRMS $m / z[M+\mathrm{H}]^{+}$calcd for $\mathrm{C}_{16} \mathrm{H}_{12} \mathrm{~N}_{2} \mathrm{O}_{2} \mathrm{Br}$ : 343.0082, found 343.0079 , LC $t_{\mathrm{R}}=3.49 \mathrm{~min},>98 \%$ purity.

6-Bromo-N-(1,3-dihydro-2-benzofuran-5-yl)quinolin-4-amine (26) was obtained as a yellow solid (148 mg, $0.433 \mathrm{mmol}, 70 \%)$ m.p. 140-142 ${ }^{\circ} \mathrm{C} ;{ }^{1} \mathrm{H}$ NMR (400 MHz, [D 6 DMSO): $\delta=11.22(\mathrm{~s}, 1 \mathrm{H}), 9.22$ (d, $J=2.0 \mathrm{~Hz}, 1 \mathrm{H}), 8.49(\mathrm{~d}, J=7.0 \mathrm{~Hz}, 1 \mathrm{H}), 8.14(\mathrm{dd}, J=9.0,1.9 \mathrm{~Hz}, 1 \mathrm{H})$, $8.08(\mathrm{~d}, J=9.0 \mathrm{~Hz}, 1 \mathrm{H}), 7.48(\mathrm{~d}, J=7.8 \mathrm{~Hz}, 1 \mathrm{H}), 7.42(\mathrm{~d}, J=2.0 \mathrm{~Hz}$, $1 \mathrm{H}), 7.37(\mathrm{dd}, J=8.0,1.9 \mathrm{~Hz}, 1 \mathrm{H}), 6.80(\mathrm{~d}, J=7.0 \mathrm{~Hz}, 1 \mathrm{H}), 5.05(\mathrm{~s}, 4 \mathrm{H})$. ${ }^{13} \mathrm{C}$ NMR (100 MHz, [D $]$ DMSO): $\delta=154.6,143.3,141.5,138.8,137.7$, 137.0, 136.6, 126.7, 125.0, 123.0, 122.8, 120.3, 119.0, 118.8, 100.8, 72.93, 72.86. HRMS $\mathrm{m} / \mathrm{z}[\mathrm{M}+\mathrm{H}]^{+}$calcd for $\mathrm{C}_{17} \mathrm{H}_{14} \mathrm{~N}_{2} \mathrm{OBr}$ : 341.0289, found 341.0286 , LC $t_{R}=3.28 \mathrm{~min},>98 \%$ purity.

$N$-(Benzo[d][1,3]dioxol-4-yl)-6-bromoquinolin-4-amine (27) was obtained as a yellow solid $(157 \mathrm{mg}, 0.458 \mathrm{mmol}, 74 \%)$. m.p.
$>270{ }^{\circ} \mathrm{C}$ decomp.; ${ }^{1} \mathrm{H}$ NMR $\left(400 \mathrm{MHz},\left[\mathrm{D}_{6}\right] \mathrm{DMSO}\right): \delta=11.21(\mathrm{~s}, 1 \mathrm{H})$ $9.24(\mathrm{~d}, \mathrm{~J}=1.9 \mathrm{~Hz}, 1 \mathrm{H}), 8.57(\mathrm{~d}, \mathrm{~J}=6.9 \mathrm{~Hz}, 1 \mathrm{H}), 8.25-8.02(\mathrm{~m}, 2 \mathrm{H})$ 7.16-6.81 (m, 3H), $6.65(\mathrm{~d}, \mathrm{~J}=6.9 \mathrm{~Hz}, 1 \mathrm{H}), 6.11(\mathrm{~s}, 2 \mathrm{H}) .{ }^{13} \mathrm{C}$ NMR (101 MHz, [D $]$ DMSO): $\delta=153.1,148.8,142.9,141.5,137.2,136.5$, $126.3,122.6,122.5,120.0,119.5,119.1,118.4,107.9,101.84,101.80$ HRMS $\mathrm{m} / \mathrm{z}[\mathrm{M}+\mathrm{H}]^{+}$calcd for $\mathrm{C}_{16} \mathrm{H}_{12} \mathrm{~N}_{2} \mathrm{O}_{2} \mathrm{Br}$ : 343.0082, found $343.0072, \mathrm{LC}_{\mathrm{R}}=3.43 \mathrm{~min},>98 \%$ purity.

6-Bromo-N-(1,3-dihydro-2-benzofuran-4-yl)quinolin-4-amine (28) was obtained as a yellow/mustard solid $(141 \mathrm{mg}, 0.414 \mathrm{mmol}$, $67 \%)$. m.p. Decomp. $>220^{\circ} \mathrm{C} ;{ }^{1} \mathrm{H}$ NMR (400 MHz, $\left.\left[\mathrm{D}_{6}\right] \mathrm{DMSO}\right): \delta=$ $10.81(\mathrm{~s}, 1 \mathrm{H}), 9.16(\mathrm{~d}, J=1.9 \mathrm{~Hz}, 1 \mathrm{H}), 8.49(\mathrm{~d}, J=6.6 \mathrm{~Hz}, 1 \mathrm{H}), 8.13-$ $7.97(\mathrm{~m}, 2 \mathrm{H}), 7.47(\mathrm{t}, J=7.6 \mathrm{~Hz}, 1 \mathrm{H}), 7.35$ (ddd, $J=21.1,7.6,0.9 \mathrm{~Hz}$, $2 \mathrm{H}), 6.47(\mathrm{~d}, J=6.5 \mathrm{~Hz}, 1 \mathrm{H}), 5.10(\mathrm{~d}, J=2.0 \mathrm{~Hz}, 2 \mathrm{H}), 4.95(\mathrm{~d}, J=$ $2.0 \mathrm{~Hz}, 2 \mathrm{H}) .{ }^{13} \mathrm{C}$ NMR (100 MHz, [D $]$ DMSO): $\delta=152.3,144.9,141.8$, $139.6,135.6,135.4,131.6,129.3,126.2,124.7,124.4,120.2,119.4$, 119.1, 101.0, 73.0, 71.5. HRMS $\mathrm{m} / \mathrm{z}[\mathrm{M}+\mathrm{H}]^{+}$calcd for $\mathrm{C}_{17} \mathrm{H}_{14} \mathrm{~N}_{2} \mathrm{OBr}$ : 341.0289 , found 341.0281 , LC $t_{\mathrm{R}}=3.25 \mathrm{~min},>98 \%$ purity.

6-Bromo-N-(3-methoxyphenyl)quinazolin-4-amine (29) was obtained as a light yellow solid (175 mg, $0.530 \mathrm{mmol}, 86 \%)$. m.p. 239$241{ }^{\circ} \mathrm{C} ;{ }^{1} \mathrm{H}$ NMR (400 MHz, [D $]$ DMSO): $\delta=11.79(\mathrm{~s}, 1 \mathrm{H}), 9.34(\mathrm{~d}, J=$ $2.0 \mathrm{~Hz}, 1 \mathrm{H}), 8.95(\mathrm{~s}, 1 \mathrm{H}), 8.24(\mathrm{dd}, J=8.9,2.0 \mathrm{~Hz}, 1 \mathrm{H}), 7.98(\mathrm{~d}, J=$ $8.9 \mathrm{~Hz}, 1 \mathrm{H}), 7.55-7.18(\mathrm{~m}, 3 \mathrm{H}), 6.97-6.83(\mathrm{~m}, 1 \mathrm{H}), 3.79(\mathrm{~s}, 3 \mathrm{H}) .{ }^{13} \mathrm{C}$ NMR $\left(100 \mathrm{MHz},\left[\mathrm{D}_{6}\right] \mathrm{DMSO}\right): \delta=159.4,158.8,151.1,138.8,138.1$ 137.6, 129.5, 127.4, 122.0, 121.0, 116.7, 115.1, 112.0, 110.6, 55.3. HRMS $\mathrm{m} / \mathrm{z}[\mathrm{M}+\mathrm{H}]^{+}$calcd for $\mathrm{C}_{15} \mathrm{H}_{13} \mathrm{~N}_{3} \mathrm{OBr}$ : 330.0242, found 330.0246 , LC $t_{\mathrm{R}}=4.80 \mathrm{~min},>98 \%$ purity.

3-[(6-Bromoquinazolin-4-yl)amino]phenol (30) was obtained as a yellow solid (154 mg, $0.487 \mathrm{mmol}, 79 \%)$ m.p. Decomp. $>250{ }^{\circ} \mathrm{C} ;{ }^{1} \mathrm{H}$ NMR (400 MHz, [D $]$ DMSO): $\delta=11.63(\mathrm{~s}, 1 \mathrm{H}), 9.82(\mathrm{~s}, 1 \mathrm{H}), 9.27(\mathrm{~d}, J=$ $2.0 \mathrm{~Hz}, 1 \mathrm{H}), 8.94(\mathrm{~s}, 1 \mathrm{H}), 8.23(\mathrm{dd}, J=8.9,2.0 \mathrm{~Hz}, 1 \mathrm{H}), 7.96(\mathrm{~d}, J=$ $8.9 \mathrm{~Hz}, 1 \mathrm{H}), 7.43-6.92(\mathrm{~m}, 3 \mathrm{H}), 6.76(\mathrm{ddd}, J=8.1,2.4,1.0 \mathrm{~Hz}, 1 \mathrm{H}) .{ }^{13} \mathrm{C}$ NMR $\left(100 \mathrm{MHz},\left[\mathrm{D}_{6}\right] \mathrm{DMSO}\right): \delta=158.7,157.7,151.1,138.7,138.1$, $137.4,129.4,127.3,122.1,120.9,115.2,115.1,113.9,111.7$. HRMS m/ $z[M+\mathrm{H}]^{+}$calcd for $\mathrm{C}_{14} \mathrm{H}_{11} \mathrm{~N}_{3} \mathrm{OBr}$ : 316.0085, found 316.0081, LC $t_{\mathrm{R}}=$ $4.20 \mathrm{~min},>98 \%$ purity.

6-Bromo-N-[3-(2H-1,2,3,4-tetrazol-5-yl)phenyl]quinazolin-4-amine (31) was obtained as a light beige solid (184 mg, $0.499 \mathrm{mmol}, 81 \%)$. ${ }^{1} \mathrm{H}$ NMR (400 MHz, [D $]$ DMSO): $\delta=11.21(\mathrm{~s}, 1 \mathrm{H}), 9.18(\mathrm{~d}, J=2.0 \mathrm{~Hz}$, $1 \mathrm{H}), 8.58(\mathrm{~d}, J=6.9 \mathrm{~Hz}, 1 \mathrm{H}), 8.23(\mathrm{t}, J=1.9 \mathrm{~Hz}, 1 \mathrm{H}), 8.19(\mathrm{dd}, J=9.0$ $2.0 \mathrm{~Hz}, 1 \mathrm{H}), 8.13(\mathrm{dt}, J=7.8,1.3 \mathrm{~Hz}, 1 \mathrm{H}), 8.08(\mathrm{~d}, J=9.0 \mathrm{~Hz}, 1 \mathrm{H}), 7.80$ $(\mathrm{t}, J=7.9 \mathrm{~Hz}, 1 \mathrm{H}), 7.72(\mathrm{ddd}, J=8.1,2.2,1.1 \mathrm{~Hz}, 1 \mathrm{H}), 7.02(\mathrm{~d}, J=$ $6.9 \mathrm{~Hz}, 1 \mathrm{H}) .{ }^{13} \mathrm{C}$ NMR (100 MHz, [D $]$ DMSO): $\delta=153.8,143.4,138.1$, 137.4, 136.7, 131.1, 127.6, 126.2, 126.0, 125.7, 123.4, 122.6, 120.1 118.8, 100.8. m.p. Decomp. $300^{\circ} \mathrm{C}$; HRMS $\mathrm{m} / \mathrm{z}[\mathrm{M}+\mathrm{H}]^{+}$calcd for $\mathrm{C}_{15} \mathrm{H}_{16} \mathrm{~N}_{6} \mathrm{Br}$ : 359.0620, found 369.0276, LC $t_{\mathrm{R}}=3.10 \mathrm{~min},>98 \%$ purity.

6-Bromo-N-(3-(pentafluoro- $\lambda^{6}$-sulfaneyl)phenyl)quinolin-4-amine (32) was obtained as a colourless solid ( $200 \mathrm{mg}, 0.470 \mathrm{mmol}, 76 \%)$. m.p. $290-292{ }^{\circ} \mathrm{C} ;{ }^{1} \mathrm{H}$ NMR (400 MHz, [D $]$ DMSO): $\delta=11.31(\mathrm{~s}, 1 \mathrm{H})$ $9.18(\mathrm{~d}, J=2.0 \mathrm{~Hz}, 1 \mathrm{H}), 8.61(\mathrm{~d}, J=6.9 \mathrm{~Hz}, 1 \mathrm{H}), 8.20(\mathrm{dd}, J=9.0$, $2.0 \mathrm{~Hz}, 1 \mathrm{H}), 8.12(\mathrm{~d}, J=9.0 \mathrm{~Hz}, 1 \mathrm{H}), 8.07(\mathrm{t}, J=2.0 \mathrm{~Hz}, 1 \mathrm{H}), 7.95(\mathrm{ddd}$, $J=8.0,2.3,1.2 \mathrm{~Hz}, 1 \mathrm{H}), 7.86(\mathrm{dt}, J=8.1,1.5 \mathrm{~Hz}, 1 \mathrm{H}), 7.81(\mathrm{t}, J=$ $8.0 \mathrm{~Hz}, 1 \mathrm{H}), 6.96(\mathrm{~d}, J=6.9 \mathrm{~Hz}, 1 \mathrm{H}) .{ }^{13} \mathrm{C} \mathrm{NMR}\left(100 \mathrm{MHz},\left[\mathrm{D}_{6}\right] \mathrm{DMSO}\right)$ : $\delta=153.8,153.5(\mathrm{t}, J=16.7 \mathrm{~Hz}), 143.5,138.2,137.4,136.7,131.0$ $129.0,126.3,124.3,122.6,122.6,120.1,118.9,100.9$. HRMS $\mathrm{m} / \mathrm{z}[\mathrm{M}+$ $\mathrm{H}]^{+}$calcd for $\mathrm{C}_{15} \mathrm{H}_{11} \mathrm{~N}_{2} \mathrm{SF}_{5} \mathrm{Br}$ : 424.9746, found 424.9736, LC $t_{\mathrm{R}}=$ $4.64 \mathrm{~min},>98 \%$ purity.

6-Bromo- $\mathrm{N}$-[3-(tert-butoxy)phenyl]quinolin-4-amine (33) was obtained as a colourless solid (170 mg, $0.458 \mathrm{mmol}, 74 \%)$ m.p. 280$282^{\circ} \mathrm{C} ;{ }^{1} \mathrm{H}$ NMR (400 MHz, [D 6 DMSO): $\delta=11.10(\mathrm{~s}, 1 \mathrm{H}), 9.17(\mathrm{~d}, J=$ $2.0 \mathrm{~Hz}, 1 \mathrm{H}), 8.54(\mathrm{~d}, J=6.9 \mathrm{~Hz}, 1 \mathrm{H}), 8.17(\mathrm{dd}, J=9.0,2.0 \mathrm{~Hz}, 1 \mathrm{H}), 8.08$ $(\mathrm{d}, J=9.0 \mathrm{~Hz}, 1 \mathrm{H}), 7.47(\mathrm{t}, J=8.0 \mathrm{~Hz}, 1 \mathrm{H}), 7.19$ (ddd, $J=7.9,2.1$, $0.9 \mathrm{~Hz}, 1 \mathrm{H}), 7.09(\mathrm{t}, J=2.2 \mathrm{~Hz}, 1 \mathrm{H}), 7.03$ (ddd, $J=8.2,2.4,0.9 \mathrm{~Hz}, 1 \mathrm{H})$, 
$6.84(\mathrm{~d}, J=6.9 \mathrm{~Hz}, 1 \mathrm{H}), 1.35(\mathrm{~s}, 9 \mathrm{H}) .{ }^{13} \mathrm{C}$ NMR $\left(101 \mathrm{MHz},\left[\mathrm{D}_{6}\right] \mathrm{DMSO}\right)$ : $\delta=156.3,154.0,143.0,137.6,137.3,136.6,130.2,126.2,122.5,122.4$ $120.1,119.8,119.7,118.6,100.5,78.8,28.5$ (s, 3 C). HRMS $\mathrm{m} / \mathrm{z}[\mathrm{M}+$ $\mathrm{H}]^{+}$calcd for $\mathrm{C}_{19} \mathrm{H}_{20} \mathrm{~N}_{2} \mathrm{OBr}$ : 371.0759, found 371.0750, LC $t_{\mathrm{R}}=$ $4.54 \mathrm{~min},>98 \%$ purity.

6-Bromo- $N$-(3-tert-butylphenyl)quinolin-4-amine (34) was obtained as a yellow solid (171 mg, $0.483 \mathrm{mmol}, 78 \%)$. m.p. 285$287^{\circ} \mathrm{C} ;{ }^{1} \mathrm{H}$ NMR $\left(400 \mathrm{MHz},\left[\mathrm{D}_{6}\right] \mathrm{DMSO}\right): \delta=11.08(\mathrm{~s}, 1 \mathrm{H}), 9.17(\mathrm{~d}, J=$ $2.0 \mathrm{~Hz}, 1 \mathrm{H}), 8.51(\mathrm{~d}, J=7.0 \mathrm{~Hz}, 1 \mathrm{H}), 8.17(\mathrm{dd}, J=9.0,2.0 \mathrm{~Hz}, 1 \mathrm{H}), 8.08$ (d, $J=9.0 \mathrm{~Hz}, 1 \mathrm{H}$ ), 7.86-7.37 (m, 3H), 7.31 (ddd, $J=7.4,2.2,1.3 \mathrm{~Hz}$, $1 \mathrm{H}), 6.83(\mathrm{~d}, J=7.0 \mathrm{~Hz}, 1 \mathrm{H}), 1.32(\mathrm{~s}, 9 \mathrm{H}) .{ }^{13} \mathrm{C} \mathrm{NMR}\left(100 \mathrm{MHz},\left[\mathrm{D}_{6}\right]\right.$ DMSO): $\delta=154.0,152.9,143.0,137.3,136.7,136.5,129.6,126.2$, $124.4,122.4,122.2,119.77,118.6,100.3,34.7,31.0$. HRMS $m / z[M+$ $\mathrm{H}]^{+}$calcd for $\mathrm{C}_{19} \mathrm{H}_{20} \mathrm{~N}_{2} \mathrm{Br}$ : 355.0810 , found 355.0800 , $\mathrm{LC} t_{\mathrm{R}}=4.99 \mathrm{~min}$, $>98 \%$ purity.

\section{Acknowledgements}

The SGC is a registered charity (no. 1097737) that receives funds from AbbVie, Bayer Pharma AG, Boehringer Ingelheim, Canada Foundation for Innovation, Eshelman Institute for Innovation, Genome Canada, Innovative Medi-cines Initiative (EU/EFPIA) [ULTRA-DD grant no. 115766], Janssen, Merck KGaA Darmstadt Germany, MSD, Novartis Pharma AG, Ontario Ministry of Economic Development and Innovation, Pfizer, São Paulo Research Foundation-FAPESP, Takeda, and Wellcome [106169/ZZ14/Z]. We also thank CSC - IT Center for Science Ltd. Finland for the use of their facilities, software licenses, computational resources and the Biocenter Finland/DDCB for financial support. The authors thank Prof. Lee Graves (University of North Carolina at Chapel Hill) for useful discussions. We are grateful to Dr. Brandie Ehrmann for LCMS/HRMS support provided by the Mass Spectrometry Core Laboratory at the University of North Carolina at Chapel Hill. We also thank the EPSRC UK National Crystallography Service for funding and collection of the crystallographic data for 13, 14, 25, 27 and 29.

\section{Conflict of Interest}

The authors declare no conflict of interest.

Keywords: anilinoquinazolines · anilinoquinolines · cyclin Gassociated kinase (GAK) • water networks · WaterMap

[1] E. D. Scheeff, P. E. Bourne, PLoS Comput. Biol. 2005, 5, e49.

[2] Z. A. Knight, K. M. Shokat, Chem. Biol. 2005, 12, 621-637.

[3] G. Manning, D. B. Whyte, R. Martinez, T. Hunter, S. Sudarsanam, Science 2002, 298, 1912-1934

[4] P. Badrinarayan, G. N. Sastry, Curr. Pharm. Des. 2013, 19, 4714-4738.

[5] S. Lu, X. He, D. Ni, J. Zhang, J. Med. Chem. 2019, 62, 6405-6421.

[6] Q. Liu, Y. Sabnis, Z. Zhao, T. Zhang, S. J. Buhrlage, L. H. Jones, N. S. Gray, Chem. Biol. 2013, 20, 146-159.

[7] W. D. Jang, J. Kim, N. S. Kang, J. Mol. Liq. 2014, 191, 37-41.

[8] W. D. Jang, M. H. Lee, N. S. Kang, J. Mol. Liq. 2016, 221, 361-322.

[9] F. Heider, T. Pantsar, M. Kudolo, F. Ansideri, A. De Simone, L. Pruccoli, T. Schneider, M. I. Goettert, A. Tarozzi, V. Andrisano, S. A. Laufer, P. Koch, ACS Med. Chem. Lett. 2019, 10, 1407-1414.
[10] S. Riniker, L. J. Barandun, F. Diederich, O. Krämer, A. Steffen, W. F. van Gunsteren, J. Comput.-Aided Mol. Des. 2012, 26, 1293-1309.

[11] R. Abel, L. Wang, R. A. Friesner, B. J. Berne, J. Chem. Theory Comput. 2010, 6, 2924-2934.

[12] Y. Yang, F. C. Lightstone, S. E. Wong, Expert Opin. Drug Discovery 2013, 8, 277-287.

[13] D. D. Robinson, W. Sherman, R. Farid, ChemMedChem. 2010, 5, 618-627.

[14] S. Kannan, M. R. Pradhan, G. Tiwari, W. C. Tan, B. Chowbay, E. H. Tan, D. S. Tan, C. Verma, Sci. Rep. 2017, 7, 1540.

[15] R. Horbert, B. Pinchuk, E. Johannes, J. Schlosser, D. Schmidt, D. Cappel, F. Totzke, C. Schächtele, C. Peifer, J. Med. Chem. 2015, 58, 170-182.

[16] N. M. Levinson, S. G. Boxer, Nat. Chem. Biol. 2014, 10, 127-132.

[17] C. R. M. Asquith, T. Laitinen, J. M. Bennett, P. H. Godoi, M. P. East, G. J. Tizzard, L. M. Graves, G. L. Johnson, R. E. Dornsife, C. I. Wells, J. M. Elkins, T. M. Willson, W. J. Zuercher, ChemMedChem 2018, 13, 48-66.

[18] C. R. M. Asquith, B. T. Berger, J. Wan, J. M. Bennett, S. J. Capuzzi, D. J. Crona, D. H. Drewry, M.P. East, J. M. Elkins, O. Fedorov, P. H. Godoi, D. M. Hunter, S. Knapp, S. Müller, C. D. Torrice, C. I. Wells, H. S. Earp, T. M. Willson, W. J. Zuercher, J. Med. Chem. 2019, 62, 2830-2836.

[19] C. R. M. Asquith, D. K. Treiber, W. J. Zuercher, Bioorg. Med. Chem. Lett. 2019, 29, 1727-1731.

[20] C. R. M. Asquith, T. Laitinen, J. M. Bennett, C. I. Wells, J. M. Elkins, W. J. Zuercher, G. J. Tizzard, A. Poso, ChemMedChem. 2020, 15, 26-49.

[21] F. J. Sorrell, M. Szklarz, K. R. Abdul Azeez, J. M. Elkins, S. Knapp, Structure 2016, 24, 401-411.

[22] H. Shimizu, I. Nagamori, N. Yabuta, H. Nojima, J. Cell Sci. 2009, 122, 3145-3152.

[23] N. Dzamko, J. Zhou, Y. Huang, G. M. Halliday, Front. Mol. Neurosci. 2014, $7,57$.

[24] M. Susa, E. Choy, X. Liu, J. Schwab, F. J. Hornicek, H. Mankin, Z. Duan, Mol. Cancer Ther. 2010, 9, 3342-3350.

[25] M. R. Ray, L. A. Wafa, H. Cheng, R. Snoek, L. Fazli, M. Gleave, P. S. Rennie, Int. J. Cancer 2006, 118, 1108-1119.

[26] S. Knapp, P. Arruda, J. Blagg, S. Burley, D. H. Drewry, A. Edwards, D. Fabbro, P. Gillespie, N. S. Gray, B. Kuster, K. E. Lackey, P. Mazzafera, N. C. Tomkinson, T. M. Willson, P. Workman, W. J. Zuercher, Nat. Chem. Biol. 2013, 9, 3-6.

[27] S. Kovackova, L. Chang, E. Bekerman, G. Neveu, R. Barouch-Bentov, A. Chaikuad, C. Heroven, M. Sala, S. De Jonghe, S. Knapp, S. Einav, P. Herdewijn, J. Med. Chem. 2015, 58, 3393-3410.

[28] S. Y. Pu, R. Wouters, S. Schor, J. Rozenski, R. Barouch-Bentov, L. I. Prugar, C. M. O'Brien, J. M. Brannan, J. M. Dye, P. Herdewijn, S. De Jonghe, S. Einav, J. Med. Chem. 2018, 61, 6178-6192.

[29] C. H. Arrowsmith, J. E. Audia, C. Austin, J. Baell, J. Bennett, J. Blagg, C. Bountra, P. E. Brennan, P. J. Brown, M. E. Bunnage, C. Buser-Doepner, R. M. Campbell, A. J. Carter, P. Cohen, R. A. Copeland, B. Cravatt, J. L. Dahlin, D. Dhanak, A. M. Edwards, M. Frederiksen, S. V. Frye, N. Gray, C. E. Grimshaw, D. Hepworth, T. Howe, K. V. Huber, J. Jin, S. Knapp, J. D. Kotz, R. G. Kruger, D. Lowe, M. M. Mader, B. Marsden, A. MuellerFahrnow, S. Müller, R. C. O'Hagen, J. P. Overington, D. R. Owen, S. H. Rosenberg, B. Roth, R. Ross, M. Schapira, S. L. Schreiber, B. Shoicet, M. Sundstrçm, G. Superti-Furga, J. Taunton, L. Toledo-Sherman, C. Walpole, M. A. Walters, T. M. Wilson, P. Workman, R. N. Young, W. J. Zuercher, Nat. Chem. Biol. 2015, 11, 536-542.

[30] M. A. Fabian, W. H. Biggs III, D. K. Treiber, C. E. Atteridge, M. D. Azimioara, M. G. Benedetti, T. A. Carter, P. Ciceri, P. T. Edeen, M. Floyd J. M. Ford, M. Galvin, J. L. Gerlach, R. M. Grotzfeld, S. Herrgard, D. E. Insko, M. A. Insko, A. G. Lai, J. M. Lelias, S. A. Mehta, Z. V. Milanov, A. M. Velasco, L. M. Wodicka, H. K. Patel, P. P. Zarrinkar, D. J. Lockhart, Nat. Biotechnol. 2005, 23, 329-336.

[31] R. Jr Roskoski, Pharmacol. Res. 2016, 103, 26-48.

[32] R. Newton, K. A. Bowler, E. M. Burns, P. J. Chapman, E. E. Fairweather, S. J. R. Fritzl, K. M. Goldberg, N. M. Hamilton, S. V. Holt, G. V. Hopkins, S. D. Jones, A. M. Jordan, A. J. Lyons, H. Nikki March, N. Q. McDonald, L. A. Maguire, D. P. Mould, A. G. Purkiss, H. F. Small, A. I. J. Stowell, G. J. Thomson, I. D. Waddell, B. Waszkowycz, A. J. Watson, D. J. Ogilvie, Eur. J. Med. Chem. 2016, 13, 20-32.

[33] C. R. M. Asquith, N. Fleck, C. D. Torrice, D. J. Crona, C. Grundner, W. J. Zuercher, Bioorg. Med. Chem. Lett. 2019, 18, 2695-2699.

[34] C. R. M. Asquith, K. M. Naegeli, M. P. East, T. Laitinen, T. M. Havener, C. I. Wells, G. L. Johnson, D. H. Drewry, W. J. Zuercher, D. C. Morris, J. Med. Chem. 2019, 62, 4772-4778.

[35] T. Machleidt, C. C. Woodroofe, M. K. Schwinn, J. Méndez, M. B. Robers, K. Zimmerman, P. Otto, D. L. Daniels, T. A. Kirkland, K. V. Wood, ACS Chem. Biol. 2015, 10, 1797-1804. 
[36] J. D. Vasta, C. R. Corona, J. Wilkinson, C. A. Zimprich, J. R. Hartnett, M. R. Ingold, K. Zimmerman, T. Machleidt, T. A. Kirkland, K. G. Huwiler, R. F. Ohana, M. Slater, P. Otto, M. Cong, C. I. Wells, B. T. Berger, T. Hanke, C. Glas, K. Ding, D. H. Drewry, K. V. M. Huber, T. M. Willson, S. Knapp, S. Müller, P. L. Meisenheimer, F. Fan, K. V. Wood, M. B. Robers, Cell Chem Biol. 2018, 25, 206-214.

[37] W. F. Baitinger, P. von R. Schleyer, T. S. S. R. Murty, L. Robinson, Tetrahedron 1964, 20, 1635-1647.

[38] L. Pauling, J. Am. Chem. Soc. 1932, 54, 3570-3582.

[39] P. R. Savoie, J. T. Welch, Chem. Rev. 2015, 115, 1130-1190.

[40] Schrödinger Maestro software package, Small-Molecule Drug Discovery Suite 2018-4, Schrödinger, LLC, New York, NY 2018.

[41] P. Politzer, J. S. Murray, T. Clark, Phys. Chem. Chem. Phys. 2013, 15, 11178-11189.

[42] L. Wang, B. J. Berne, R. A. Friesner, Proc. Natl. Acad. Sci. USA. 2011, 108, 1326-1330.

[43] a) F. M. Ferguson, N. S. Gray, Nat. Rev. Drug Discovery 2018, 17, 353-377, b) http://www.brimr.org/PKI/PKIs.htm.

[44] P. Cohen, D. R. Alessi, ACS Chem. Biol. 2013, 8, 96-104.

[45] A. F. Rudolf, T. Skovgaard, S. Knapp, L. J. Jensen, J. Berthelsen, PLoS One 2014, 9, e98800.

[46] M. I. Davis, J. P. Hunt, S. Herrgard, P. Ciceri, L. M. Wodicka, G. Pallares, M. Hocker, D. K. Treiber, P. P. Zarrinkar, Nat. Biotechnol. 2011, 29, 10461051.

[47] H. Ma, S. Deacon, K. Horiuchi, Expert Opin. Drug Discovery 2008, 3, 607621.

[48] a) A. J. Kooistra, G. K. Kanev, O. P. van Linden, R. Leurs, I. J. de Esch, C. de Graaf, Nucleic Acids Res. 2016, 44, D365-D371; b) O. P. van Linden, A. J. Kooistra, R. Leurs, I. J. de Esch, C. de Graaf, J. Med. Chem. 2014, 57, 249-277.

[49] D. Robinson, T. Bertrand, J. C. Carry, F. Halley, A. Karlsson, M. Mathieu, H. Minoux, M. A. Perrin, B. Robert, L. Schio, W. Sherman, J. Chem. Inf. Model. 2016, 56, 886-894.
[50] P. Czodrowski, G. Hölzemann, G. Barnickel, H. Greiner, D. Musil, J. Med. Chem. 2015, 58, 457-465.

[51] V. Myrianthopoulos, M. Kritsanida, N. Gaboriaud-Kolar, P. Magiatis, Y. Ferandin, E. Durieu, O. Lozach, D. Cappel, M. Soundararajan, P. Filippakopoulos, W. Sherman, S. Knapp, L. Meijer, E. Mikros, A. L. Skaltsounis, ACS Med. Chem. Lett. 2013, 4, 22-26.

[52] N. Ohbayashi, K. Murayama, M. Kato-Murayama, M. Kukimoto-Niino, T. Uejima, T. Matsuda, N. Ohsawa, S. Yokoyoma, H. Nojima, M. Shirouzu, ChemistryOpen. 2018, 7, 721-727.

[53] T. Young, R. Abel, B. Kim, B. J. Berne, R. A. Friesner, Proc. Natl. Acad. Sci. USA. 2007, 104, 808-813.

[54] R. Abel, T. Young, R. Farid, B. J. Berne, R. A. Friesner, J. Am. Chem. Soc 2008, 130, 2817-2831.

[55] D. Cappel, W. Sherman, T. Beuming, Curr. Top. Med. Chem. 2017, 17, 2586-2598.

[56] E. Harder, W. Damm, J. Maple, C. Wu, M. Reboul, J. Y. Xiang, L. Wang, D. Lupyan, M. K. Dahlgren, J. L. Knight, J. W. Kaus, D. S. Cerutti, G. Krilov, W. L. Jorgensen, R. Abel, R. A. Friesner, J. Chem. Theory Comput. 2016, 12, 281-296.

[57] C. R. M. Asquith, J. M. Bennett, L. Su, T. Laitinen, J. M. Elkins, J. E. Pickett, C. I. Wells, Z. Li, T. M. Willson, W. J. Zuercher, Molecules 2019, 24, 4016.

[58] CrysAlisPro Software System, Rigaku Oxford Diffraction 2018.

[59] G. M. Sheldrick, Acta Crystallogr. Sect. A 2015, 71, 3-8.

[60] G. M. Sheldrick, Acta Crystallogr. Sect. C 2015, 71, 3-8.

[61] O. V. Dolomanov, L. J. Bourhis, R. J. Gildea, J. A. K. Howard, H. Puschmann, J. Appl. Crystallogr. 2009, 42, 339-341. 
Navigating water ways: To understand better how water networks influence drugs in general and kinase inhibitors in particular, we have elucidated the properties of a proposed water network with cyclin G-associated kinase (GAK) by using a targeted point mutation library. This can be used as a tool towards more potent GAK inhibitors and to enhance wider inhibitor design.

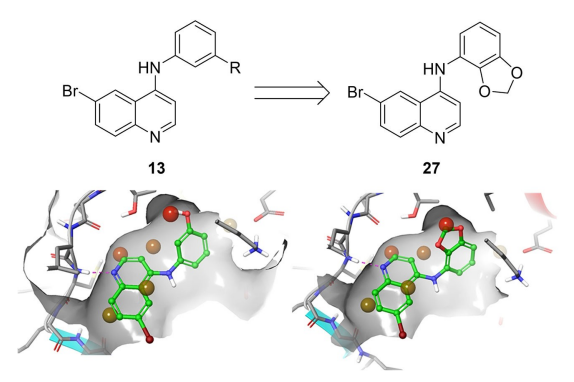

Dr. C. R. M. Asquith*, Dr. G. J. Tizzard, J. M. Bennett, C. I. Wells, Dr. J. M. Elkins, Prof. T. M. Willson, Prof. A. Poso, Dr. T. Laitinen

$1-17$

Targeting the Water Network in Cyclin G-Associated Kinase (GAK) with 4-Anilino-quin(az)oline Inhibitors

Targeting the water network in cyclin G-associated kinase (GAK) with 4-anilino-quin(az)oline inhibitors (Asquith et al. @UNCResearch @TropMedOxford @UniEastFinland @uni_tue OK?)

Share your work on social media! ChemMedChem has added Twitter as a means to promote your article. Twitter is an online microblogging service that enables its users to send and read short messages and media, known as tweets. Please check the pre-written tweet in the galley proofs for accuracy. If you, your team, or institution have a Twitter account, please include its handle @username. Please use hashtags only for the most important keywords, such as \#catalysis, \#nanoparticles, or \#proteindesign. The ToC picture and a link to your article will be added automatically, so the tweet text must not exceed 250 characters. This tweet will be posted on the journal's Twitter account (follow us @ ChemMedChem) upon publication of your article in its final (possibly unpaginated) form. We recommend you to re-tweet it to alert more researchers about your publication, or to point it out to your institution's social media team.

\section{ORCID (Open Researcher and Contributor ID)}

Please check that the ORCID identifiers listed below are correct. We encourage all authors to provide an ORCID identifier for each coauthor. ORCID is a registry that provides researchers with a unique digital identifier. Some funding agencies recommend or even require the inclusion of ORCID IDs in all published articles, and authors should consult their funding agency guidelines for details. Registration is easy and free; for further information, see http://orcid.org/.

Carrow I. Wells

James M. Bennett

Dr. Graham J. Tizzard

Dr. Tuomo Laitinen

Prof. Antti Poso

Dr. Jonathan M. Elkins

Prof. Timothy M. Willson

Dr. Christopher R. M. Asquith http://orcid.org/0000-0001-5871-3458 